

\section{DISCLAIMER}

This report was prepared as an account of work sponsored by an agency of the United States Government. Neither the United States Government nor any agency Thereof, nor any of their employees, makes any warranty, express or implied, or assumes any legal liability or responsibility for the accuracy, completeness, or usefulness of any information, apparatus, product, or process disclosed, or represents that its use would not infringe privately owned rights. Reference herein to any specific commercial product, process, or service by trade name, trademark, manufacturer, or otherwise does not necessarily constitute or imply its endorsement, recommendation, or favoring by the United States Government or any agency thereof. The views and opinions of authors expressed herein do not necessarily state or reflect those of the United States Government or any agency thereof. 


\section{DISCLAIMER}

Portions of this document may be illegible in electronic image products. Images are produced from the best available original document. 


\title{
REPORT ON THE MARK II BNL STANDARD COBALT RADIATION SOURCE, BONDED TYPE
}

\author{
0.A. Kuhl, A. Oltmann, and J. Wagner
}

LEGAL NOTICE

This report was prepared as an account of Government sponsored work. Neither the United States $_{2}$ nor the Commission, nor any person acting on behalf of the Commission:

A. Makes any warranty or representation, expressed or implied, with respect to the aeeu racy, completeness, or usefulness of the information contained in this report, or that the use of any information, apparatus, method, or process disclosed in this report may not infringe privately owned rights; or

B. Assumes any liabilities with respect to the use of, or for damages resulting from the of any information, apparatus, method, or process disclosed in this report.

As used in the above, "person acting on behalf of the Commission" includes any employee or contractor of the Commission, or employee of such contractor, to the extent that such employee or contractor of the Commission, or einpluyee of such contractor prepares, disseminates, or provides access to, any information pursuant to his employment or contract with the Commission, or his employment with such contractor.

RETEASED TOR ANTOUNCEVENT

IN RUCLEAX SCIENCE AESTRACIS

\section{April 1966}




\section{E G A L N O T I C E}

This report was prepared as an account of Government sponsored work. Neither the United States, nor the Commission, nor any person acting on behalf of the Commission:

A. Makes any warranty or representation, expressed or implied, with respect to the accuracy, completeness, or usefulness of the information contained in this report, or that the use of any information, apparatus, method, or process disclosed in this report may not infringe privately owned rights; or

B. Assumes any liabilities with respect to the use of, or for damages resulting from the use of any information, apparatus, method, or process disclosed in this report.

As used in the above, "person acting on behalf of the Commission" includes any employee or contractor of the Commission, or employee of such contractor, to the exten that such employee or contractor of the Commission, or employee of such contractor prepares, disseminates, or provides access to, any information pursuant to his employment or contract with the Commission, or his employment with such contractor.

\section{PRINTED IN USA}

PRICE $\$ 2.00$

Available from the

Clearinghouse for Federal Scientific and Technical Information

National Bureau of Standards

U.S. Department of Commerce

Springfield, Virginia

November 1966

625 copies 


\begin{abstract}
A brief history of radiation source development at $\mathrm{BNL}$ and a discussion of source design factors preface a description of the latest design of the BNL standard cobalt radiation source. This is identified as the BNL Mark II bonded-type source. Specifications, a description of methods for testing for compliance with the specifications, and the results of these tests are included.
\end{abstract}




\section{REPORT ON THE MARK II BNL STANDARD COBALT RADIATION SOURCE, BONDED TYPE}

Radiation source development work at Brookhaven National Laboratory (BNL) has progressed through a number of designs. ${ }^{1}$ Originally, the main uses of a cobalt source were for small-scale research. The cobalt was generally of low specific activity, 2 to $5 \mathrm{Ci} / \mathrm{g}$, and the users generally employed one or two elements in a physical form compatible with an inexpensive irradiator designed for the exposure of small samples. Units designed by the Radiation Division of the Nuclear Engincering Department at BNL utilized a lead container housing a tubular source. A removable plug with a canister attached provided for the exposure of small samples to a radiation field (Figure 1). The tubular source consisted of a tube of cobalt placed between concentric tubes of stainless steel. The ends of the tubes were welded to form an encapsulation around the cobalt (Figure 2). The source was then irradiated in the Brookhaven Graphite Research Reactor (BGRR).

Another source design, which might be called the father of the BNL Mark I standard source, is the BNL flat source. These rather large strips (Figure 3) were also activated in the BGRR. They found service in pool irradiator facilities (Figure 4) and in containers designed to house a number of the strips, such as the irradiators used in the U.S. Department of Agriculture's screwworm fly eradication program (Figure 5). The increasing size of research and demonstration facilities and concomitant use of $\mathrm{Co}^{60}$ sources, together with the potential of large-scale industrial radiation processing, indicate the desirability of some type of source standardization.

In the design of a source, certain factors must be considered, e.g.,

1. Physical Form. The physical form must be compatible with reactor and large-scale irradiator requirements.

2. Self-Absorption. A source should be designed to minimize the self-absorption of its energy in order to maximize its utilization efficiency and minimize the self-heating. It might be noted here that in a way this is also true during reactor irradiation. The en- capsulation should be minimal so that only the useful material, i.e., $\mathrm{Co}^{59}$, is irradiated. The cobalt thickness must be optimized from the curie production standpoint, so that the cobalt is not black to neutrons and does not cause undue flux depression.

3. Fabrication. The techniques of fabrication must lend themselves to the production of a safe, reliable, and economic source element.

4. Encapsulation. The initial and final encapsulation materials must be compatible with the en vironments of the activation reactors and of the irradiators in which the source element will be used.

Other considerations will become obvious as this report is read.

The BNL Mark I standard flat strip source ${ }^{2}$ shown in Figures 6 and 7 was a first attempt at designing a source for gencral use. This source is being used satisfactorily in a number of facilities the BNL High Intensity Radiation Development Laboratory, Marine Products Development Irradiator at Gloucester, Mass., Bulk Grain Irradiator, Mobile Irradiator, Shipboard Irradiator, and others. A large plaque formed from standard strip sources is shown in Figure 8. Although this type of source has not failed or shown deficiencies in use, so far as is known, it was thought that it could be improved to cover a wider range of potential uses, some involving much higher specific activities. This led to the development of the Mark II bonded $\mathrm{Co}^{60}$ source (Figures 9, 10, and 11). The primary difference between the Mark I and Mark II sources is that in the latter the first stainless steel encapsulation is metallurgically bonded to the cobalt. This results in four obvious advantages:

1. Better heat transfer is attained.

2. Integrity of the encapsulation is vastly improved, and thus gross contamination problems are minimized.

3. There is less waste space or dead volume per source element (this includes air space and any space occupied by the encapsulation material at the edges of the element), which permits a greater concentration of curies per square centimeter in the assembly of any large plaque. 


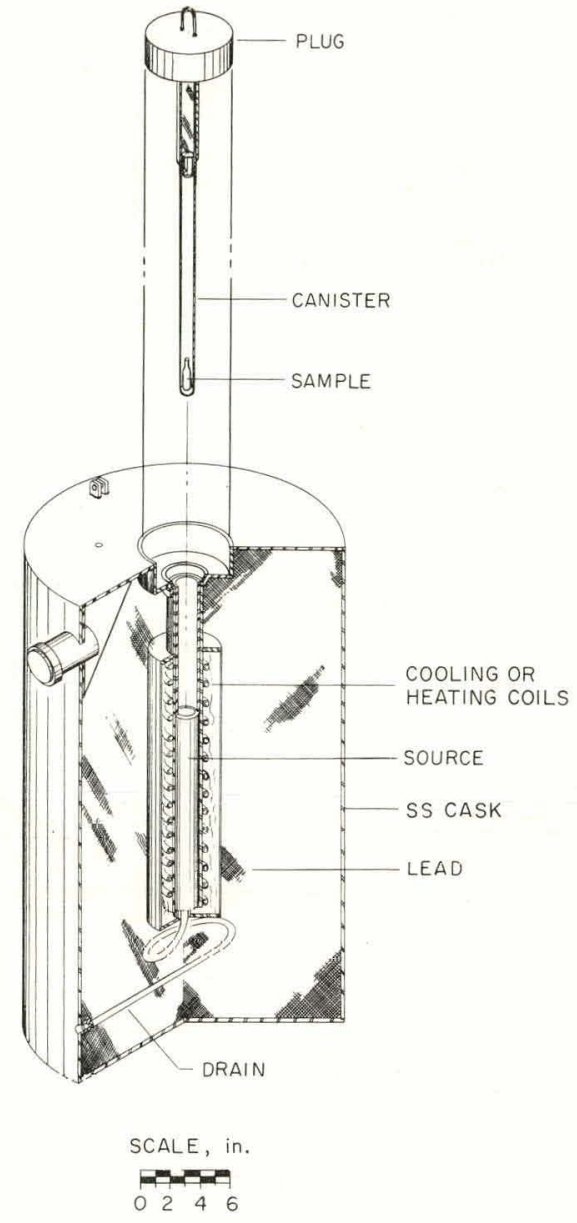

Figure 1. Tubular source container.

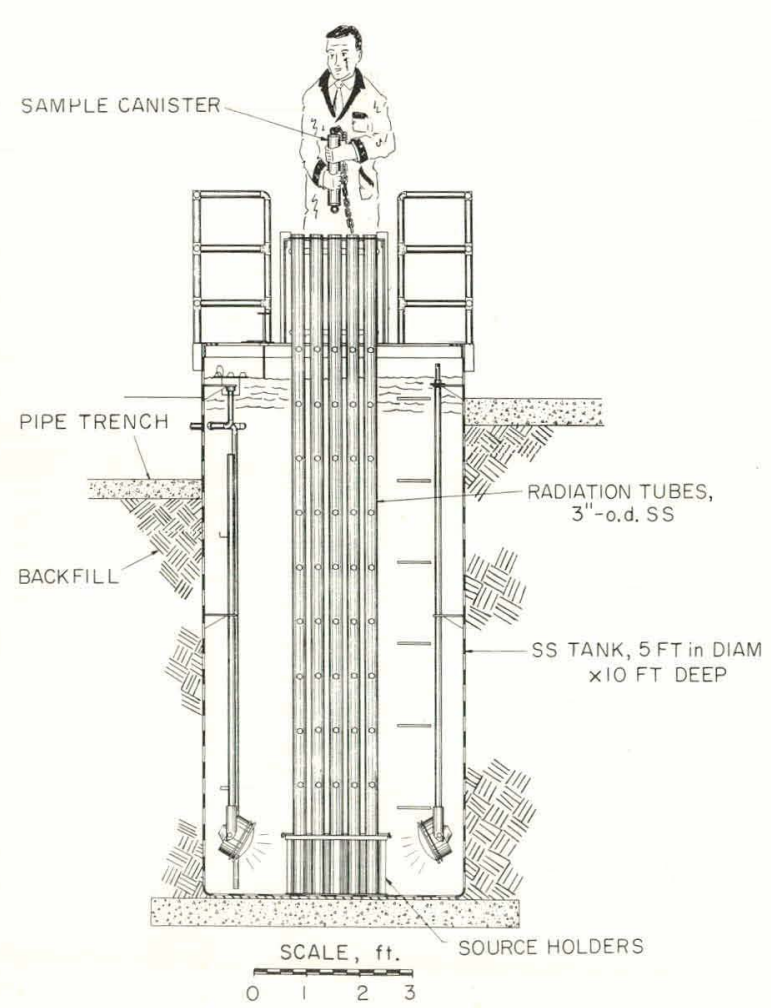

Figure 4. Foreign Exhibit Irradiator.

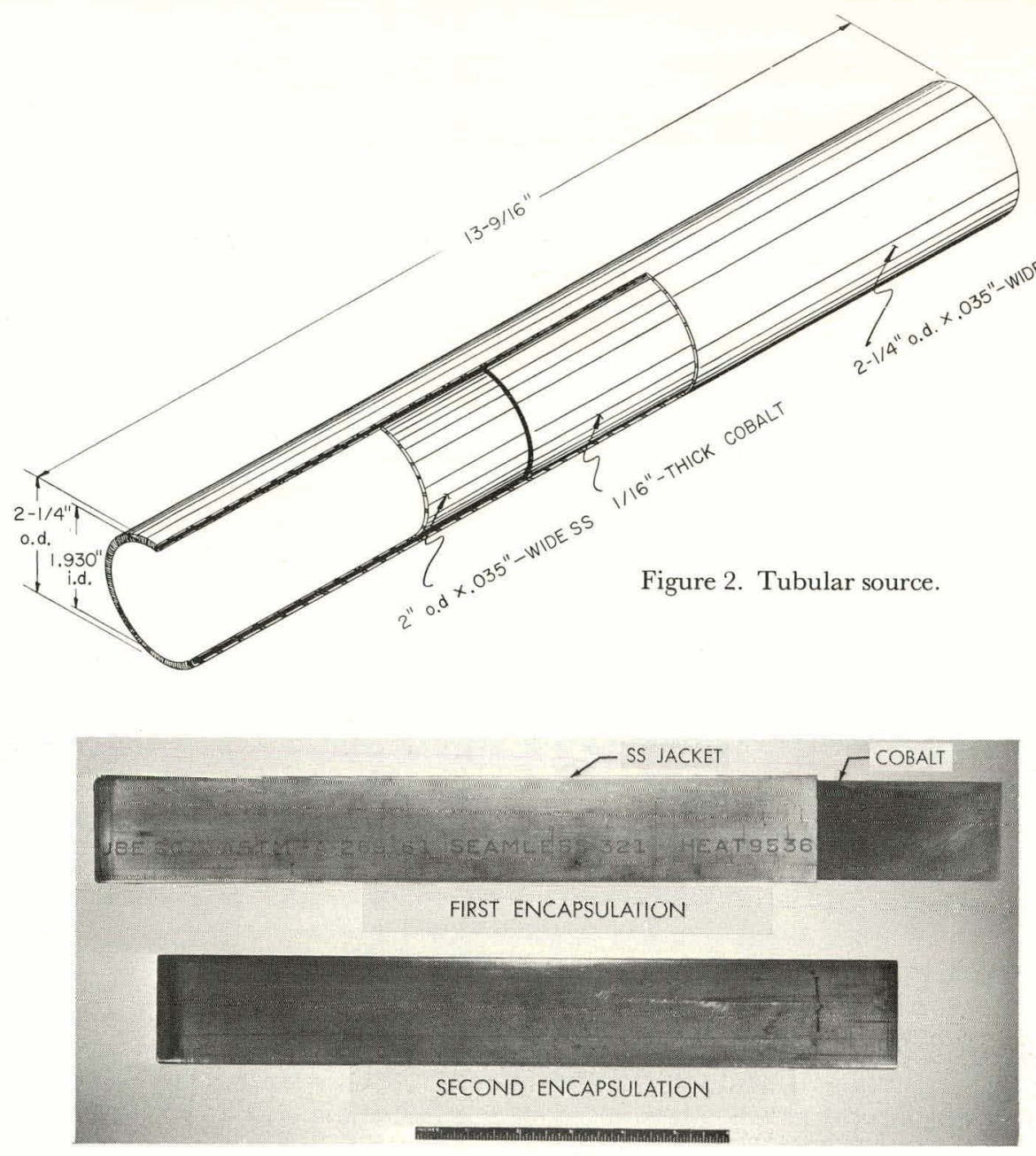

Figure 3. BNL flat source.

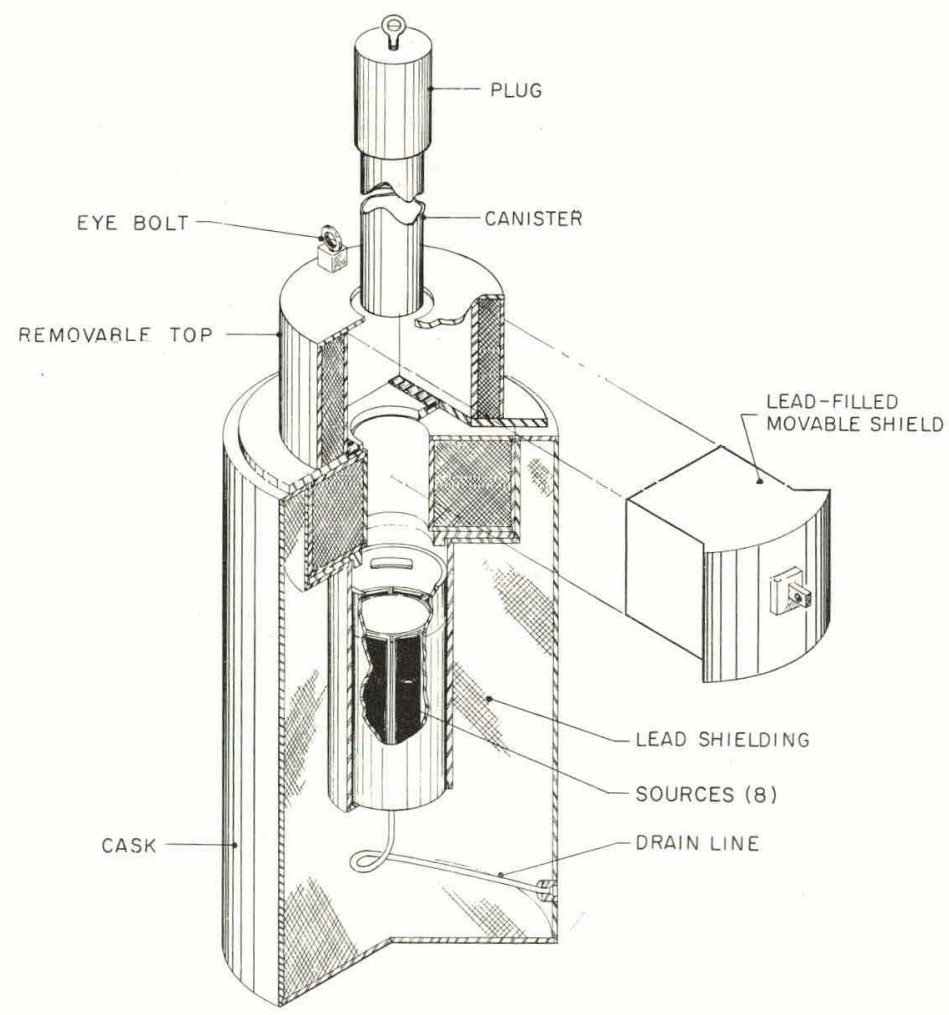

Figure 5. U.S. Department of Agriculture's Irradiator. 


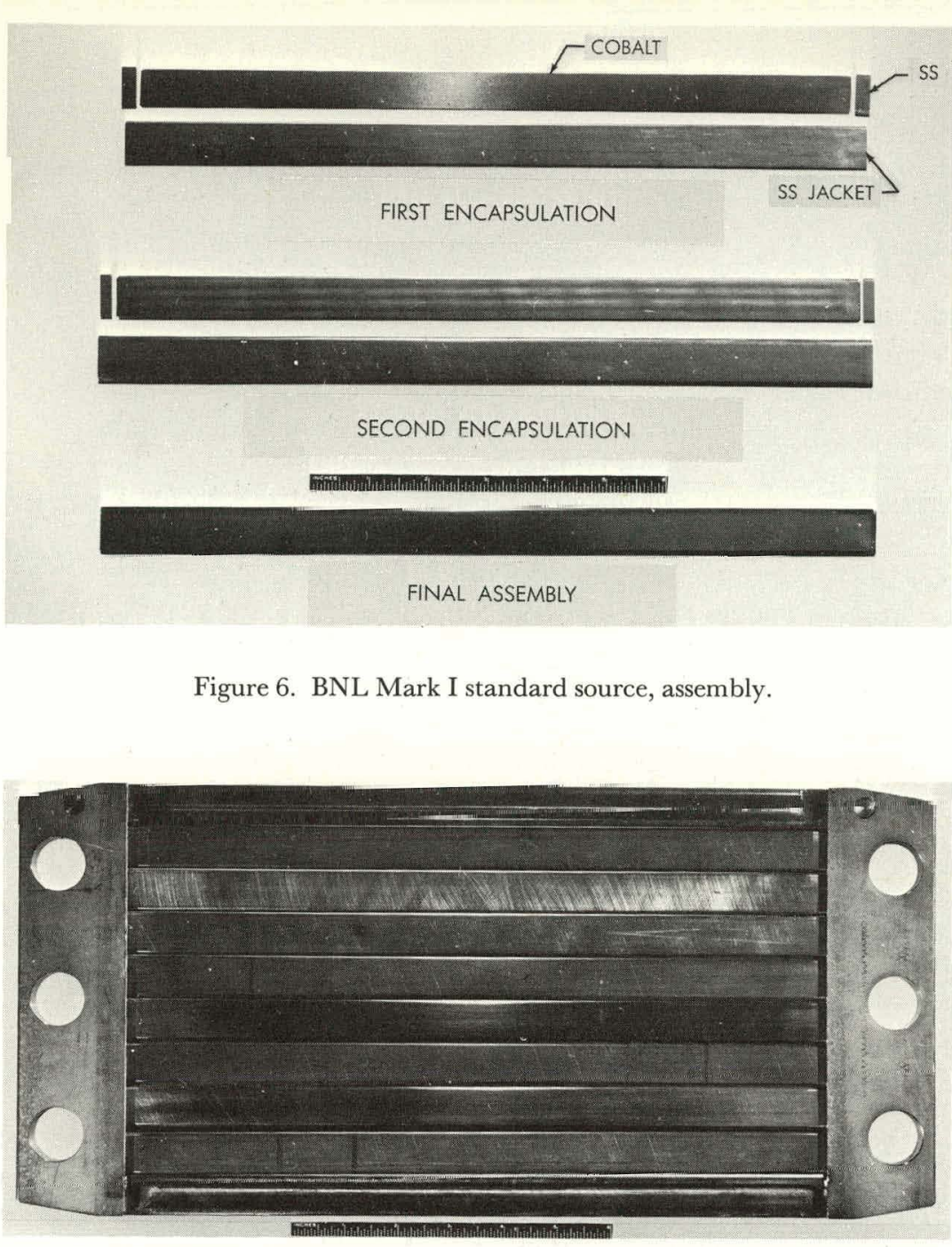

Figure 8. Marine Products Development Irradiator holder.

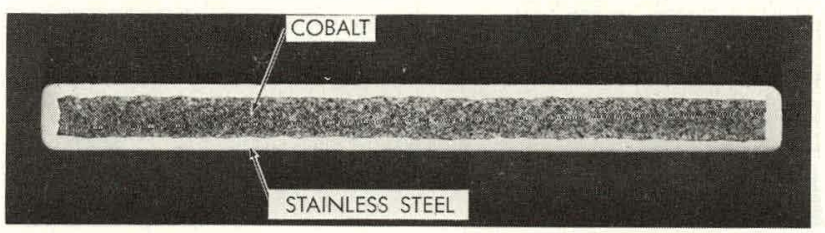

Figure 9. BNL Mark II bonded $\mathrm{Co}^{60}$ source, cross section perpendicular to major axis.

Figure 11. BNL Mark II bonded $\mathrm{Co}^{60}$ source, assembly.

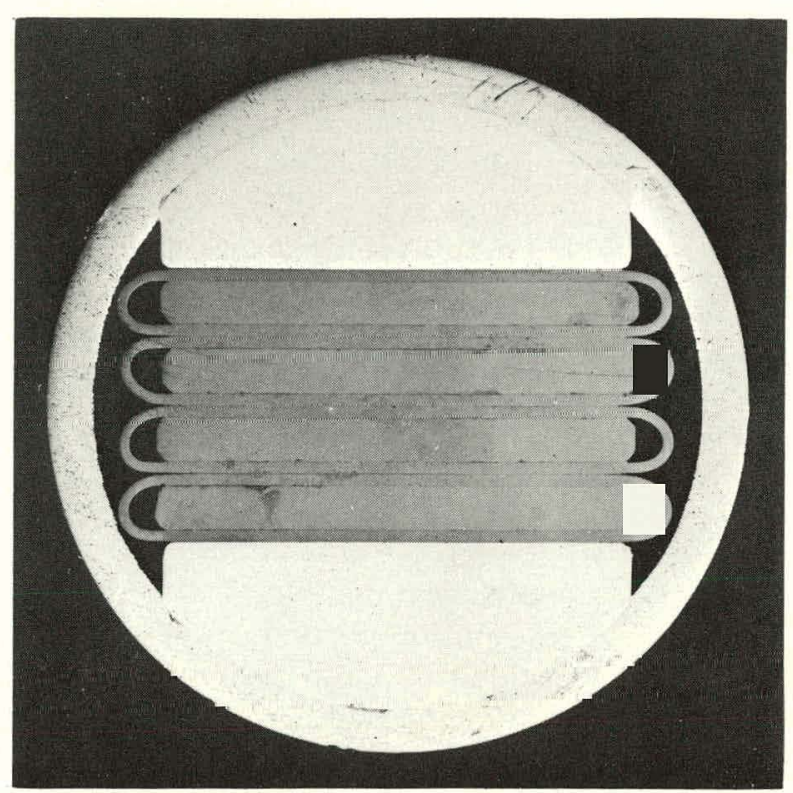

Figure 7. BNL Mark I standard source, cross section, activation slug.

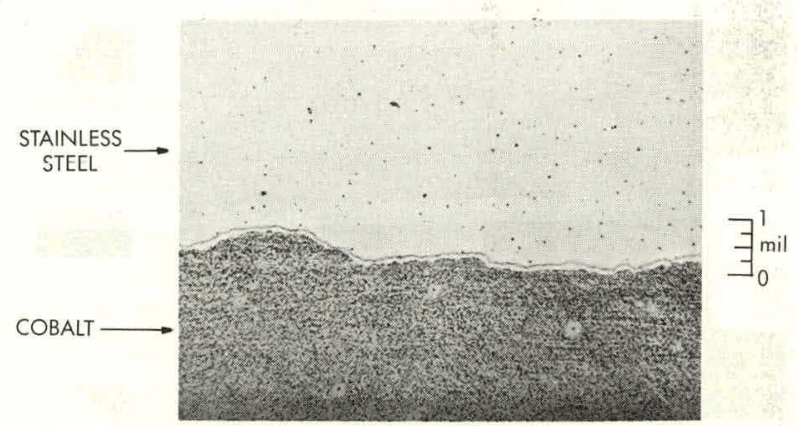

Figure 10. Typical bond area, BNL Mark II bonded $\mathrm{Co}^{60}$ source. Cross section perpendicular to major axis shows bond line between cobalt and cladding. 
4. In general, further encapsulation, such as in the four-strip activation slug arrangement for the Mark I source (Figure 7), is not required for reactor irradiation. This minimizes the hot-cell decanning operation after activation. In addition, the arrangement of four strips in a holder (Figure 11) permits source reactivation after utilization for one or two half-lives.

The following is a description of the design, qualification tests, and nondestructive tests (NDT) developed to check some source parameters.

In the development of the specifications for the Mark II bonded source, several basic design parameters were established besides the requirements for a metallurgical bond between the cobalt and the first encapsulation material. It was decided that the design should be compatible with methods of fabrication now available in the metalforming industry. Another consideration was the need for interchangeability with the BNL Mark I source, but only after the second encapsulation had been applied. A major concern was the establishment of test procedures both for the initial qualification tests at the AEC's Savannah River Plant (SRP) reactor facility and for the subsequent production tests. In the past, $10 \%$ of all Mark I standard sources were destructively tested.

After a preliminary specification and shop drawing had been submitted to SRP and some minor changes made, the specification and drawing shown in Appendix A were sent to eight or ten interest in the development of the source. Visits were made to their plants or their representatives came to BNL. Three different techniques were proposed by the fabricators. They were roll-bonding, coextrusion, and plating. The first two showed good promise; the plating process was held in abeyance, since it had the least chance of being approved by SRP without a massive test program.

An invitation to bid on 50 sources was sent to the interested fabricators. This not only resulted in getting cost figures, but also brought out some exceptions to the basic specification. Samples were submitted by two or three vendors.

With this information on hand, another conference was held with E.I. du Pont de Nemours and Co. at SRP. Preliminary approval of the specification, qualification test methods, and source holder (Figure 10) was obtained. The decision was made to purchase 300 sources, 60 of which were to be used for testing. Emphasis was placed on developing NDT test methods.

Invitations to bid were again sent out to eight interested concerns. The choice narrowed down to three companies; two proposed to use the rollbonding method and one planned to coextrude the source. Prices in all three cases were within $10 \%$ of each other. However, the companies that proposed the roll-bonding method wanted an exception in the edge distance between the cladding and the cobalt. The roll-bonding process does not produce a straight, controllable interface along the edges of the flat strip. Since it was thought at BNL that the thickness of the cladding should be uniform on all parts of the strip in order to minimize the amount of dead material, the decision was made to award the contract to the Nuclear Metals Division of Textrnn, Inr., who planned to use the coextrusion process. The first 60 sources were delivered and put through an intensive test program using both destructive and nondestructive techniques. SRP received six of these sources for evaluation. The results of this program are shown in greater detail in Appendices B and C. Minor changes in the fabrication process were made and the remainder of the total order of 300 strips was produced.

As a result of the evaluation of the entire run of 300 pieces, the specifications will be revised for use in future fabrication. A change of major interest to BNL is the approval by SRP of a reduction in the cladding thickness from 0.015 to 0.010 in. By keeping the same outside dimensions, this change will increase the amount of cobalt from 52 to $\approx 65$ $\mathrm{g} /$ strip. This source, when put into production, will be known as the BNL Mark III bonded source, and again will be completely interchangeable with its two predecessors in the second encapsulation.

\section{SECOND ENCAPSULATION}

The second encapsulation (see Figure 12) consists of a 13-in.-long piece of rectangular tubing and two end pieces. The material used for all three parts is type $316 \mathrm{~L}$ stainless steel. The tubing is purchased from a well-known fabricator, who will be able to supply all future demands from the same set of dies.

One of the goals has thus been achieved, and a source has been designed that can be completely fabricated commercially and does not require any 


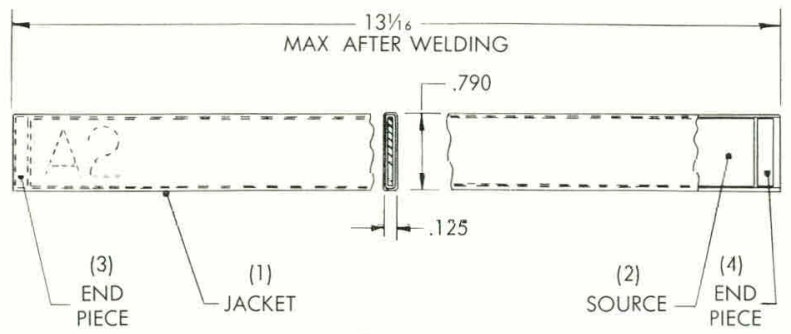

ASSEMBLY INSTRUCTIONS:

1. WELD ITEM 3 TO TUBE 1 AND LEAK-TEST BEFORE ENCAPSULATION.

2. ADD CODE NUMBER AT SAME END AS SHOWN ABOVE.

3. IN HOT CELL, REMOTELY INSERT ITEM 2, COBALT-SOURCE.

4. ALSO REMOTELY INSERT ITEM 4, TAPERED END PIECE, UNTIL FLUSH WITH TUBE. WELD AND LEAK-TEST.

Figure 12. BNL Mark II bonded $\mathrm{Co}^{60}$ source, second encapsulation.

Table 1

Chemical Analysis of Cobalt*

\begin{tabular}{cccccc}
\hline $\mathrm{Co}+\mathrm{Ni}$ & $\mathrm{Ni}$ & $\mathrm{Cu}$ & $\mathrm{Fe}$ & $\mathrm{S}$ & $\mathrm{C}$ \\
\hline 99.9 & 0.3 & 0.005 & 0.0018 & 0.001 & 0.012
\end{tabular}

*Supplier: Kulite-Tungsten Co., Ridgefield, N. J.

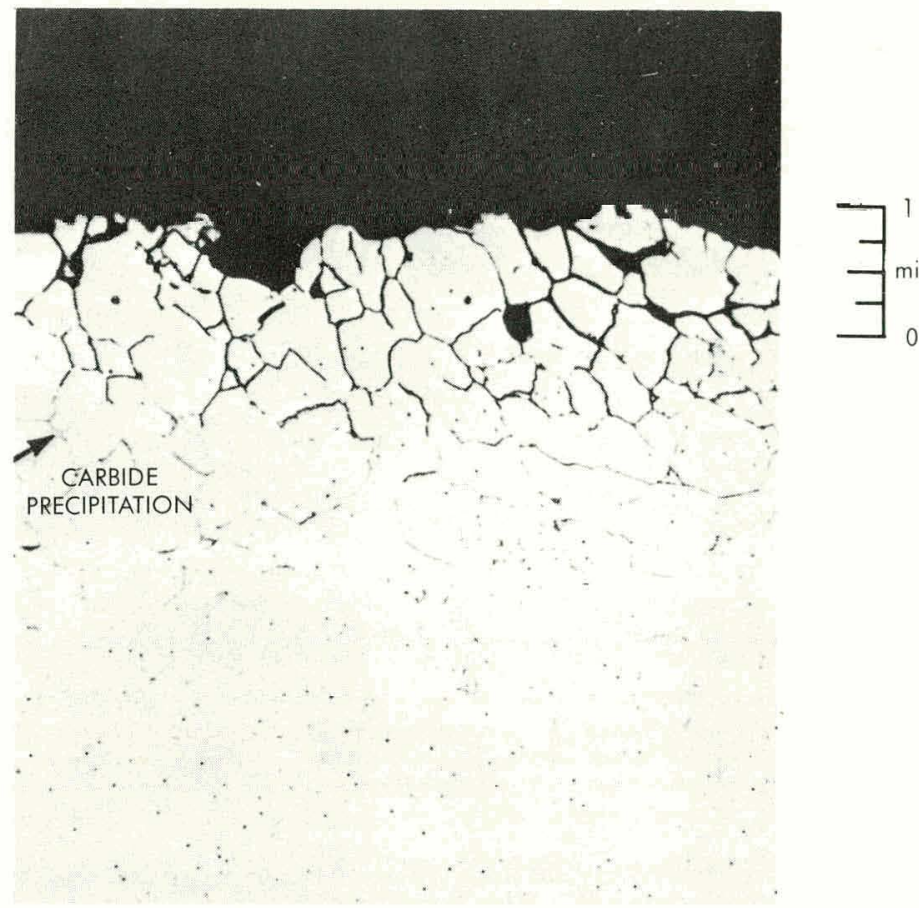

Figure 13. BNL Mark II bonded $\mathrm{Co}^{60}$ source. Cross scction perpendicular to major axis shows outer surface of cladding with carbide precipitation at grain boundaries.

Table 2

Chemical Analysis of 316L Stainless Steel

\begin{tabular}{lcccccccccc}
\hline Heat No. & G & Mn & P & S & Si & Cr & Ni & Mo & Cu & Co \\
\hline 821213 & 0.027 & 1.39 & 0.021 & 0.010 & 0.40 & 17.16 & 13.00 & 3.41 & 0.15 & 0.04 \\
26540 & 0.024 & 1.25 & 0.011 & 0.023 & 0.50 & 17.51 & 13.45 & 2.50 & 0.10 & 0.06 \\
3342970 & 0.022 & 1.77 & 0.022 & 0.017 & 0.50 & 17.88 & 13.45 & 2.54 & Not reported \\
\multicolumn{1}{r}{ Av } & 0.024 & 1.47 & 0.018 & 0.17 & 0.47 & 17.52 & 13.30 & 2.48 & 0.13 & 0.05 \\
\hline
\end{tabular}

special handling at BNL. Although the final end weld has to be made in a hot cell, several industrial firms are capable of handling this operation.

\section{QUALITY CONTROL}

The use of NDT procedures was emphasized in order to find a way to reduce the percentage of destructive examinations previously used on the Mark I source, and to discover fast and inexpensive methods of checking a much larger percentage of the entire lot.

Samples were examined for the following: dimensions, cladding thickness, weight of cobalt, end weld quality, integrity of metallurgical bond, overall homogeneity, and sensitization of the stainless steel cladding.

In the first lot of 60 sources, the major problems were corrosion sensitization of the stainless steel cladding (Figure 13) and unsatisfactory end welds. The sensitization problem appeared to be solved in the second and third lots. The weld problem was solved after consultation with a BNL welding specialist.

Chemical analyses of the cobalt and stainless steel used are given in Tables 1 and 2, respectively. Details of test procedures and results are given in Appendices B and C. 


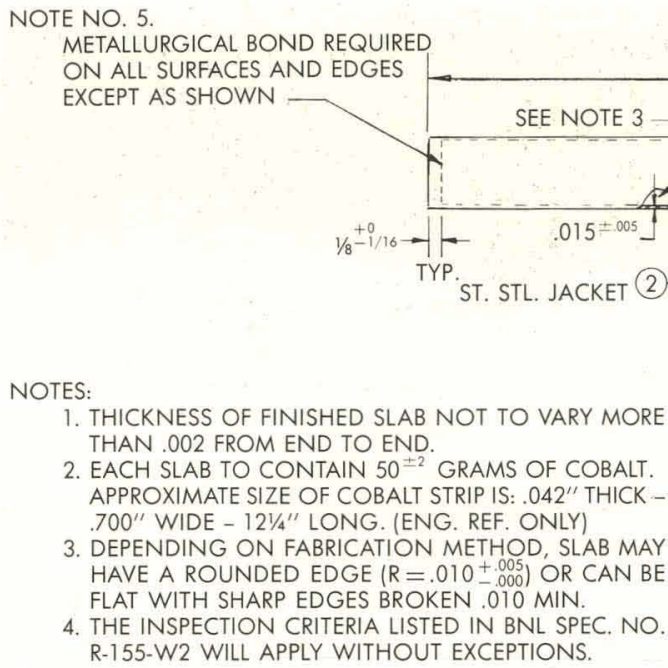

ITEM 1: REACTOR GRADE COBALT $99.5 \%$ MINIMUM PURITY (SEE NOTE 2).

ITEM 2: TYPE 316 STAINLESS STEEL. TYPE $316 L$ IF WELDING IS USED IN FABRICATION SUCH AS CLOSING ENDS. COBALT CONTENT NOT TO EXCEED $0.3 \%$. FINISH: ALL COMPLETED PARTS TO BE PASSIVATED IN ACCORDANCE WITH ASTM SPEC. NO. A380-57, PARAGRAPH $4 B$.

Figure A-1. Fabricatiun dıawing of BNL Mark II bonded $\mathrm{Co}^{60}$ source.

\section{ACKNOWLEDGMENTS}

The authors are indebted to R. Stoenner and E. Norton, BNL Chemistry Department; to J. Austin, Hot Laboratory Division, BNL Nuclear Engineering Department; to A. Beckwith, BNL Quality Control Section; and to A. Becht and C. Davis, High Intensity Radiation Development Laboratory, for their assistance in the quality control test development and in the testing.

\section{REFERENCES}

1. A. Oltmann and O.A. Kunl, Gamma Radiation Source and Irradiator Design, ASME Paper No. 65-WA/NE-2, Nov. 1965.

2. A. Ot.tmann and O.A. Kunl, Fabrication of BNL Standard Cobalt-60 Source, BNL 848 (T-334), Feb. 1964.

\section{APPENDIX A}

\section{INSPECTION CRITERIA FOR METALLURGICALLY BONDED, STAINLESS STEEL CLAD COBALT SLABS}

The cobalt slabs must comply with the following inspection criteria besides the tolerances shown in Figure A-1.

1. Slab bow is not to exceed 0.02 in. total indicator reading per foot of length parallel with major axis and 0.0025 per inch of width parallel with minor axis.
2. Cladding thickness must be $0.015 \pm 0.005$ in. and will be determined by destructive examination of representative slabs or by nondestructive examination of all slabs in a lot. The cladding must be free of dents. Scratches or gouges must not exceed 0.005 in. on either the cladding surface or the weld bead (if the process calls for welding the ends). Cladding thickness under gouges or scratches must not be $<0.010$ in.

3. Weld penetration and throat must equal minimum cladding thickness.

4. Welds must not be cobalt contaminated. The amount of cobalt contamination must not exceed the percentage of cobalt normally present in stainless steel.

5. Weld overhang must not exceed 0.005 in.

6. Total nonbonded area must not exceed $5 \%$ of total specified bondcd arca. $\Lambda$ ir gaps at nonbonds must not exceed 0.002 in. Excessive gaps will be detecled by nondestructive examination of all slabs and destructive examination of representative slabs. Excessive gaps in a slab found by nondestructive examination will be cause for rejection of the slab.

7. Each slab must be leak-tight; those that leak will be rejected. Both BNL and SRP will leak-test all slabs by using a kerosene bubble test at 28 in. vacuum.

8. Each sectioned part of each slab destructively tested will be examined for foreign material; its 
presence will be sufficient cause for the rejection of the entire lot.

9. Slab twist must not exceed $5^{\circ} / \mathrm{ft}$ of length.

10. Ends must be square with sides within 0.015 in. 11. The vendor finally selected will make a sample run. This and the associated quality control tests will be witnessed by personnel from BNL and SRP. Approval of the sample run and the tests will constitute BNL and SRP approval of the vendor's method.

12. All samples of slabs selected for destructive examination will be given a nondestructive examination before the destructive examination is made, and the results will be recorded. The record of the results and all cut samples will be sent to BNL.

\section{APPENDIX B}

\section{QUALITY CONTROL TEST PROCEDURES, BNL MARK II STANDARD COBALT RADIATION SOURCE, STAINLESS STEEL CLAD, BONDED TYPE}

\section{Bow}

Bow was measured by using a feeler gauge and surface plate.

\section{Ila. Cladding Thickness on Faces}

Method:

Decrease in force on a magnet with distance from a magnetic substrate.

Apparatus:

Aminco-Brenner Magne-gage P-3069, American Instrument Co., Silver Spring, Md.

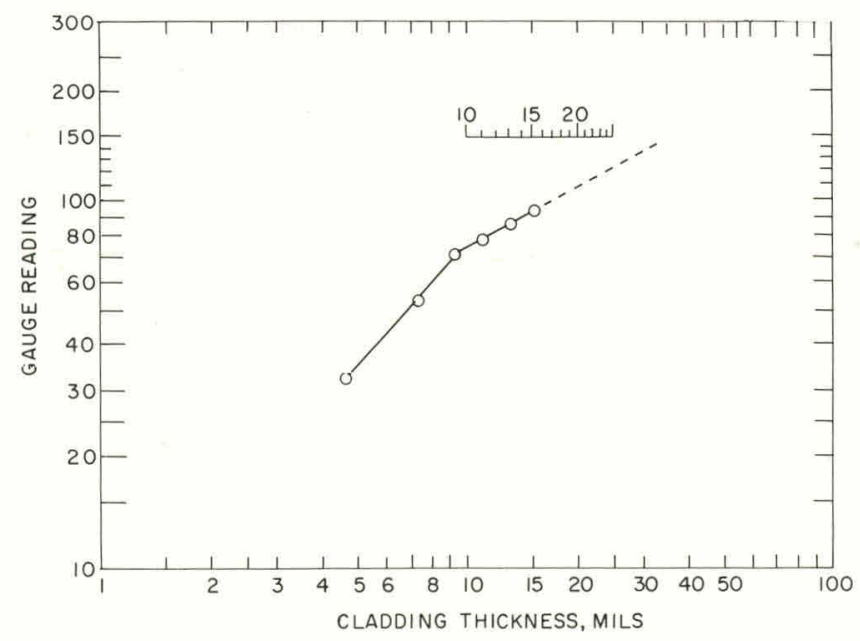

Figure B-1. Calibration curve for Magne-gage.

\section{Galibration:}

1. Removed cladding from a production specimen in measured increments.

2. Polished cross section at thin end.

3. Located cobalt interface with stain (saturated solution of $\mathrm{CuSO}_{4} \cdot 5 \mathrm{H}_{2} \mathrm{O}$ in 1 to $2 \% \mathrm{HNO}_{3}$ ).

4. Measured the thickness of the areas.

5. Prepared calibration curve (Figure B-1).

Procedure:

Started 1 in. from one end and measured thickness. Measurements were made every inch from starting point along the center line. Repeated on other side.

\section{Ilb. Cladding Thickness on Edges}

Method:

Standard radiographic technique recording on $\mathrm{x}$-ray photographic film. Measured dimensions from radiograph.

Apparatus:

Radiograph:

X-ray machine: Baltospot 200, manufactured by Balteau Electric Corp., Stamford, Conn.

Film: Kodak $M$, Kodak $A A$.

Screens: 0.005-in.-thick lead.

Developer: General Electric Industrial XRay Developer.

Dimension Measurements:

Sheffield Cordax Coordinate Measuring Machine, Model 200.

Procedure:

Radiograph:

\begin{tabular}{llll} 
& \multicolumn{1}{c}{ Face } & & \multicolumn{1}{c}{ Edge } \\
Source-to-film distance & 36 in. & & 36 in. \\
Screen location & Front and back & & Front and back \\
Penetration settings & $10(200 \mathrm{kV})$, & & $10(200 \mathrm{kV})$, \\
& $\begin{array}{l}\text { Kodak } M \\
\end{array}$ & & Kodak $M$ \\
& $6(120 \mathrm{kV})$, & \\
& Kodak $A A$ & \\
Exposure & $40 \mathrm{sec}$ & & $5 \mathrm{~min}$ \\
Film development & $3 \mathrm{~min}, 68^{\circ} \mathrm{F}$ & & $3 \mathrm{~min}, 68^{\circ} \mathrm{F}$
\end{tabular}

Dimension Measurements:

Measurements were made near each corner of the specimen in the cobalt-vacant space.

\section{IIc. Cladding Thickness on Ends}

Method:

Measured dimensions from radiograph.

Apparatus:

Radiograph:

Same as IIb above.

Dimension Measurements:

Same as IIb above. 
Procedure:

Radiograph:

Same as IIb above.

Dimension Measurements:

Measurements were made across the entire specimen width at the thinnest points. Corners were included as part of this measurement.

\section{Ild. Cladding Thickness Under Holes}

\section{A. BNL Procedure:}

Method:

Dye penetrant test: penetration of liquid dyes into cracks, crevices, and voids by capillary attraction. The presence of the dye is subsequently revealed by a developer.

Apparatus:

Standard Magnaflux Zyglo equipment.

Magnaflux Zyglo materials:

Cleaner ZC-7,

Zyglo Penctrant ZL-2,

Emulsifier ZT-3 (sulfur-free),

Dry Powder Developer ZP-4A (sulfur-free),

BNL Test Block Z-1.

Progedure for Detection of

Surface Voids and Gracks:

1. Gleaned with ZC-7.

2. Immersed in ZL-2 penetrant for 10 to 15 $\min$.

3. Wiped off excess penetrant.

4. Immersed in emulsified ZE-3 for 5 min.

5. Washed in tap water.

6. Dried in forced-circulation oven.

7. Inspected under ultraviolet light.

8. Immersed in developer powder ZP-4A for $15 \mathrm{~min}$.

9. Inspected under ultraviolet light.

10. Wiped off powder.

11. Gleaned with ZC-7.

Specification for Test Block Z-1:

Material: Aluminum.

Size: $2 \times 5 \frac{3}{3} \times 1 \frac{11 / 4}{4}$ in.

Test Holes: Seven, as follows:

\begin{tabular}{|c|c|c|}
\hline & Depth of hole, in. & $\begin{array}{l}\text { Diam of hole al } \\
\text { surface, in. }\end{array}$ \\
\hline A & 0.003 & 0.0035 \\
\hline B & 0.006 & 0.0045 \\
\hline C & 0.009 & 0.0065 \\
\hline $\mathrm{D}$ & 0.014 & 0.008 \\
\hline $\mathrm{E}$ & 0.015 & 0.007 to 0.0085 \\
\hline $\mathrm{F}$ & 0.018 & 0.007 to 0.009 \\
\hline G & 0.024 & 0.009 to 0.010 \\
\hline
\end{tabular}

The holes were made by pressing a jig-mounted steel needle into the aluminum block to form a tapered hole. The depth of the hole was measured by (a) measuring the length of the needle, (b) measuring the distance from the top of the needle to the surface of the test block, with the needle in the hole, and (c) subtracting results of measurement (b) from measurement (a). The final result is the depth of the hole. The diameter of the hole at the surface of the test block was measured optically with a toolmaker's microscope, $60 \times$.

Procedure for Calibration of Test Block Z-1:

1. Cleaned test block with ZC-7.

2. Immersed in Zyglo penetrant ZL-2 for 10 min.

3. Wiped off excess penetrant.

4. Immersed in ZE-3 emulsifier for a measured period of time.

5. Washed in tap water.

6. Dried in forced-air-circulation oven.

7. Inspccted under ultraviolet light.

8. Immersed in ZP-4A dry developer.

9. Reinspected under ultraviolet light. Observed and recorded the size of holes still visible, and the time in step 4.

10. Cleaned with ZC-7.

11. Repeated procedure with a different time for step 4.

12. Prepared calibration table (B-1).

Procedure for Estimation

of Size and Surface Voids:

After a surface void had been detected, the procedure used to calibrate Test Block Z-1 was followed, except that in stcp 9 the observation made was whcther or not the void was visible. If it was, the procedure was repeated, with the time of immersion in the emulsifier (step 4) increased. If it was not, the time was decreased. This procedure was repeated until a maximum emulsification

Table B-1

\begin{tabular}{cccc}
\hline $\begin{array}{c}\text { Test } \\
\text { hole }\end{array}$ & Diam, in. & Depth, in. & $\begin{array}{c}\text { Max length } \\
\text { of time emulsified } \\
\text { and still visible }\end{array}$ \\
\hline A & 0.0035 & 0.003 & $2 \mathrm{~min}$ \\
B & 0.0045 & 0.006 & $6 \mathrm{~min}$ \\
G & 0.0065 & 0.009 & $10 \mathrm{~min}$ \\
D & 0.008 & 0.014 & $>3 \mathrm{hr}$ \\
E & 0.007 to 0.0085 & 0.015 & $>3 \mathrm{hr}$ \\
F & 0.007 to 0.009 & 0.018 & $>3 \mathrm{hr}$ \\
G & 0.009 to 0.010 & 0.024 & $>3 \mathrm{hr}$ \\
\hline
\end{tabular}


time was found for which the void was still visible. The size of the void was determined from the calibration table with use of this time value.

\section{B. Nuclear Mefals Inc. (NMI) Procedure:}

\section{Zyglo Inspection Procedure for} Cobalt/Stainless Steel Strips:

1. Strips were thoroughly degreased with Zyglo precleaner No. ZG-7 and wiped dry.

2. Strips were then placed in wire baskets and immersed in penetrant ZL-22 until completely covered, and then placed above the penetrant to drip for $5 \mathrm{~min}$. Because of the extreme sensitivity of the penetrant, it was found that 5 min was long enough to locate any flaws. A longer time in the penetrant resulted in a heavy background on the strip and made evaluation almost impossible.

3. Strips were then immersed in emulsifier ZE-3 and left in the solution for $5 \mathrm{~min}$.

4. After removal from the emulsifier, the strips were placed on a rinse rack and all surface penetrant and emulsifier were removed by a water spray.

5. Strips were then wiped dry and examined under black light to determine if all the penetrant had been removed from the strips. Welded ends of strips appeared to be completely free of penetrant, while the remainder of the strip showed slight background.

6 . Strips were then immersed in dry powder developer ZP-4A until they were coated.

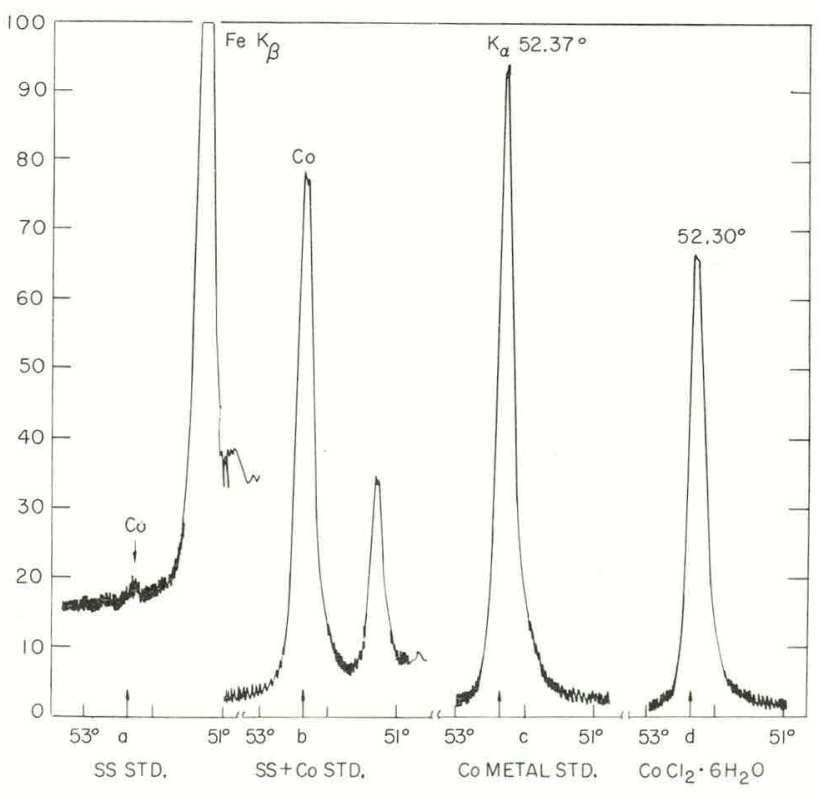

Figure B-2. Tests for cobalt contamination in end welds.
7. The final step was the inspection of the strip under black light, and then evaluation.

\section{Illa. Weld Penetration and Throat}

Method and Apparatus:

Standard radiographic technique (see IIb above). Procedure:

Entire weld was examined for thinnest area, and thickness at this point was measured.

\section{IIIb. End Weld Contamination by Cobalt}

A. BNL Method:

Fluorescent x-ray. Intensity of cobalt $K_{\alpha}$ line at 2 theta $52.37^{\circ}$ was used as measurement of cobalt concentration.

Apparatus:

Phillips Bulk Spectrograph Model 52343 was used with tungsten white excitation radiation. The machine was modified by substituting a cylindrical shield for that furnished with the machine. The shield was long enough to hold the specimen, its long axis perpendicular to the plane of the Mylar film support in the standard specimen holder. The specimen was adjusted so that the end weld was resting on the Mylar film support. Specimen-tospecimen orientation was held constant.

Specific spectrograph conditions used for this test were

Crystal: LiF,

Power: $40 \mathrm{kV}, 40 \mathrm{~mA}$,

Counter: Scintillation at $850 \mathrm{~V}$,

Slits: Fine, 1 in. entrance, 4 in. exit,

Pulse height discriminator: None,

Base line voltage setting: 0.35 units.

Calibration:

The standard used was a specimen of $316 \mathrm{~L}$ stainless steel of similar geometry and with the end fusion-welded. Wet chemical analysis for cobalt was 0.083 wt \% (Figure B-2a). The second standard was a weld made on an unplugged specimen as cut from the strip (Figure B-2b). The weld bead contained $\approx 50 \mathrm{vol} \%$ cobalt. The third and fourth standards were pure cobalt metal $(99.5 \%)$ and cobalt chloride, respectively (Figures B-2c and B-2d). Procedure:

Each specimen was scanned between 2 theta $51^{\circ}$ and $53^{\circ}$. Peak height at $52.37^{\circ}$ was compared with that of the four standards. Typical scans of two specimen welds are shown in Figures B-3a and B-3b. Precision of the methods appears to be satisfactory, as shown by Figures B-3c and B-3d, which are repeat runs of Figure B-3a and B-3b respectively. 


\section{B. NMI Method:}

This is also a fluorescent x-ray method. The intensity of the cobalt $K_{\alpha}$ beam is estimated by measuring the time for a given count to be reached by the $\mathrm{x}$-ray counting device. This time is compared with that for a blank of the stainless steel used for the cladding. In this case, the average time for the blank was $10 \mathrm{sec}$. The shorter the time, the greater is the concentration of cobalt.

\section{IIlc. Weld Overhang}

Weld overhang was measured by using a surface plate and feeler gauge. This was done after removal with a file of as much overhang as possible.

\section{IVa. Test for Bond Integrity and Voids}

Method:

Ultrasonic test reflection using pulse-echo technique.

Apparatus:

Sperry UM 721 Reflectoscope with 10 N PulserReceiver,

Special Function Cabinet UM 710,

Transigate 50C753,

Transigraph 50E543,

Alden Alfac Facsimile Recorder,

Automation Industries High Resolution Search Transducer.

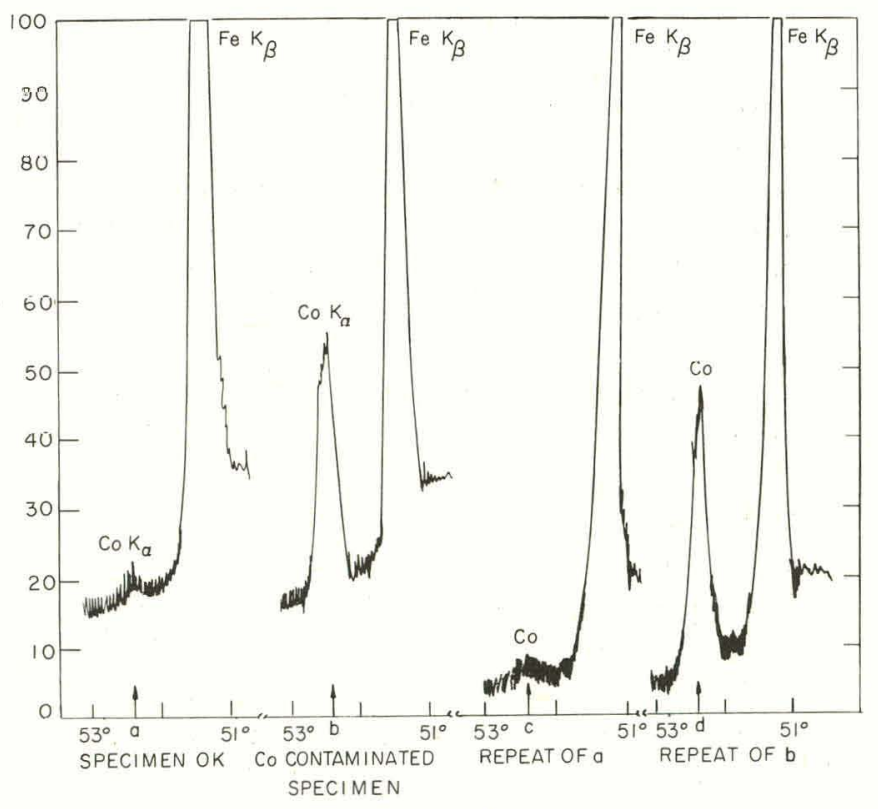

Figure B-3. Tests for cobalt contamination in end welds.
Galibration:

The standard was a specimen in which two flatbottom holes, $1 / 8$ in. in diam, had been drilled. The bottoms of the holes were located 0.015 and 0.020 in. below the surface, respectively. A piece of tape was placed over the open end of each hole to insure a metal-air interface.

Part A of Figure B-4 is a photograph of the standard; Part B shows the ultrasonic response to the standard. A discontinuity appears as a contrasting white area. The large discontinuity shown at one end of the standard was due to a reduction in thickness of the specimen in that area. Over the thin area the signals reflected from the front and back surfaces moved closer together and fell into the gate and thus showed up as a discontinuity.

To test the sensitivity of the method for detection of narrow air gaps, a test standard was made by milling two voids into the surface of a cobalt strip. The voids were $1 / 1 / 1$ in. wide, $1 / 2$ in. long, and $1 / 4$ and $3 / 4$ mil deep, respectively. A 0.020 -in.-thick stainless steel sheet was soldered to the cobalt slab over the voids. Part B of Figure B-4 shows the result of this calibration. Both voids were clearly detected. The discontinuities other than the standard voids are probably due to lack of bonding by the solder.

Procedure:

The specimen was immersed in distilled water and examined on both sides at a frequency of 10 megacycles. The response was gated to a metal travel of $0.020 \mathrm{in}$. The standard was run immediately before each test. The specimens were examined in lots of six plus the test standard, and they rested on a stainless steel plate during examination. Data presentation was on $C$ scan recording, about 46 lines/in.

\section{IVb. Thermal Test for Over-All Continuity}

Method:

The heat-scan technique described by D.R. Maley* was used.

In this technique a heat source of restricted area that scans the surface of the specimen in a controlled pattern is employed. The result was heat application of known sequence over the surface. Surface temperature was then measured with an infrared radiometer. The differences in thermal

\footnotetext{
*Paper presented at 1965 Spring National Convention of Society for Nondestructive Testing, Los Angeles, Calif., Automation Industries Paper No. TR-65-25, February 1965.
} 


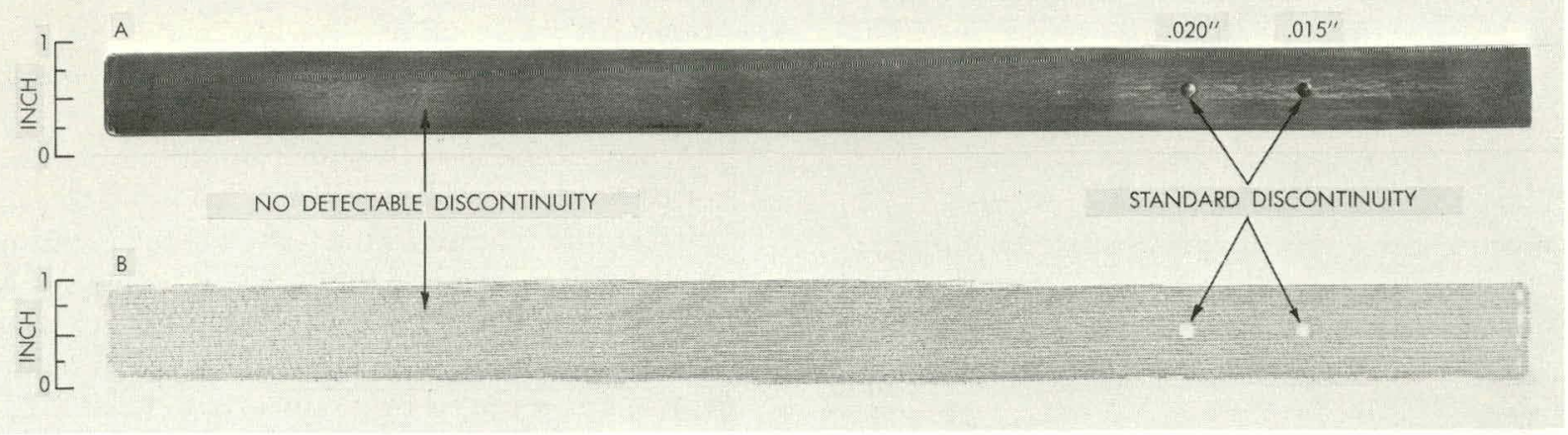

Figure B-4. Response of ultrasonic test to standard discontinuities in a stainless steel clad bonded cobalt source. $A$, photograph of standard; $B$, ultrasonic response to standard.

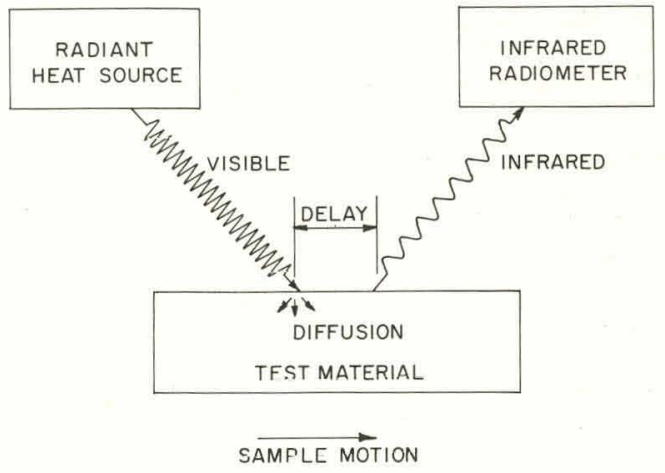

Figure B-5. Basis for thermal evaluation of materials.

conductivity within the specimen appear as temperature differences of the surface. A schematic diagram is shown in Figure B-5.

Apparatus:

Radiometer: Automation Industries Standard AII at $143 / 4$-in. focus, with indium antimonide window detector.

Heat source: Two 1000-W tungsten filament lamps, adjusted to $\approx 70 \%$ of maximum intensity. A heat spot of $\approx 5 / 8 \times 3 / 4$ in. was obtained by focusing from the front surface mirror.

\section{Procedure:}

Specimen preparation: The surfaces were coated with a dispersion of lampblack in $99 \%$ methanol, then dried under ambient room conditions.

Scanning and data presentation: Specimen scan speed was $0.5 \mathrm{in}$./sec with a $5 / 8$-in. delay. All scans were made from left to right on both sides of the

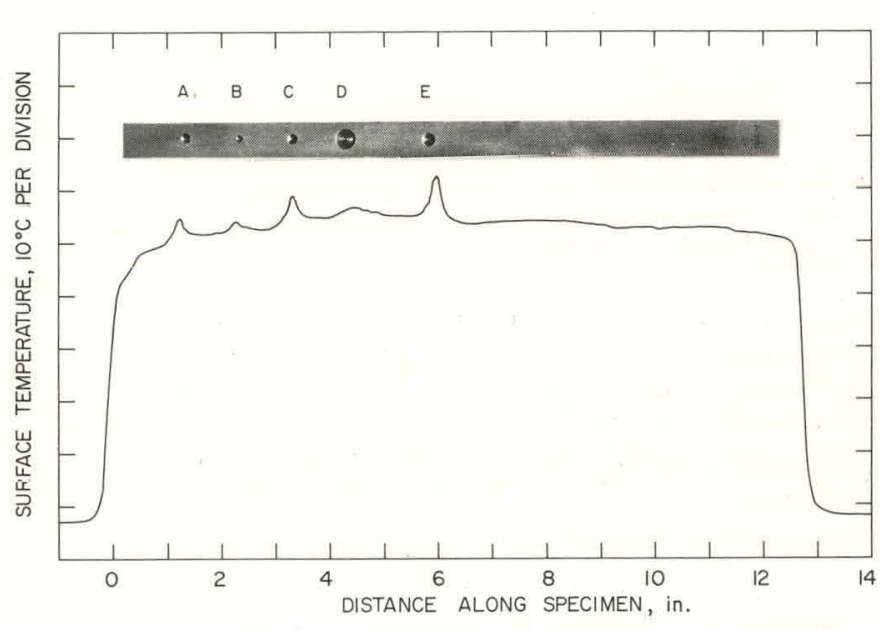

Figure B-6. Heat-scan of stainless steel clad bonded cobalt source with known defects.

specimen along the long axis. Data presentation was on an $X, Y$ recorder. The vertical $(r)$ scale was the temperature, $10^{\circ} \mathrm{C} /$ in.; the horizontal $(X)$ scale was the distance in inches along the long axis of this specimen.

\begin{tabular}{c} 
Time, min \\
\hline 0 \\
1 \\
2 \\
$3 \frac{1}{2} 2$ \\
5
\end{tabular}

Test sequence

started heating sample

finished heating sample

scanned $3 / 16$ in. below center of sample scanned on center of sample

scanned $3 / 16$ in. above center of sample

Calibration Standard:

A specimen was used in which four flat-bottom holes of the following diameters were drilled: $1 / 8$, $3 / 16,1 / 4$, and $3 / 8$ in. A fifth hole, $5 / 32$ in. in diameter, resulted in deformation of the surface, either because of local thinness of the cladding or because of slightly deeper drilling. 

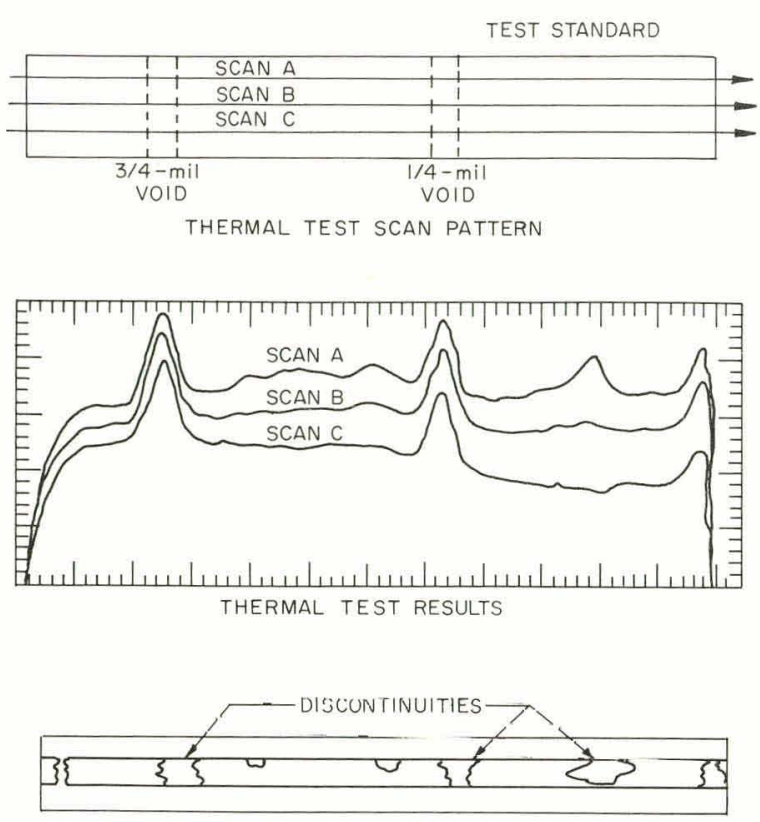

ULTRASUINIC TEST RFSIII TS, SCAN C PRESENTATION

Figure B-7. Response of thermal and ultrasonic tests to a thin air gap. The standard was made by milling 2 voids, $1 / 4$ in. wide, $1 / 2$ in. long, and $1 / 2$ and $3 / 4$ mil decp, respectively, into the surface of a cobalt strip. A 20 -mil-thick stainless steel sheet was soldered to the cobalt slab over the voids.

The thermal heat scan test reveals differences in thermal conductivity throughout the specimen. For example, an air void shows up as a surface temperature increase. This is shown in the response to the test standard (Figure B-6). Peak $A$ shows the responsc from the 5/32-in.-diam hole, over which the surface was deformed; Pcak $B$, the $1 / 8$-in-diam hole with no deformation; Peak $C$, the 3/16-in.-diam hole; Peak $D$, the $3 / 8$-in.-diam hole; and Peak $E$, the 1/4-in.-diam hole. Holes $A, B, C$, and $E$ were drilled to within 15 mils from the front surface. Hole $D$ was drilled to within 60 mils from the front surface, or 15 mils deep from the back surface. The test holes were drilled along the center line of the major axis. To check performance of the equipment during examination of specimens, the test standard was run at the start and then after every 8 to 10 specimens. The response curves were nearly identical in each case.

The thermal test has been shown to be sensitive enough to detect an air void, $1 / 4$ mil thick $x \approx 1 / 4$ in. wide $\times \approx^{1 / 2}$ in. long, at the interface of a composite of 20-mil-thick 316L stainless steel soldered to 40-mil-thick cobalt. (See Figure B-7.)

\section{Leak Tesł}

Method:

Vacuum bubble test of specimen under kerosene [see BNL 848 (T-334)].

This method is not applicable to the bonded source because the air volume is too small to give a detectable reading. This was shown by testing one defective specimen that had a channel going from an outside surface opening to the interior void between cobalt core and end plug. The channel was first revealed by a radiograph.

\section{Foreign Materials}

\section{A. Nondestructive Tests:}

The ultrasonic and thermal tests described in IVa and $\mathrm{b}$ were also used to detect foreign matcrials.

\section{B. Destructive Tests:}

Metallographic examination was used.

\section{Squareness of Ends}

The squarencss of ends was measured by using a solid square, a feeler gauge, and a surface plate.

\section{Twist}

The twist was measured by using a surface plate and a dial indicator.

\section{IXa. Cobalt Weight}

\section{A. Gravimetric Method, NMI:}

1. From each primary strip, "as-extruded," a sample $\approx 1 / 2$ in. long was cut from the front, middle, and end. The front is the first part of the strip through the die (Figure B-8).

2. Each sample was then measured for length, dried, weighed, and placed in aqueous nitric acid solution $\left(50\right.$ vol $\left.\% \mathrm{HNO}_{3}\right)$ until the cobalt was dissolved.

3. After the cobalt was removed, the sample was dried and weighed again. The weight of cobalt per unit length was calculated.

4 . The total weight of cobalt per source strip was obtained by multiplying the weight per inch by 12.425 in., the assumed average length of cobalt.

\section{B. Gravimetric-Radiograph (GR) Method:}

1 . The weight of cobalt per unit length was determined by the NMI method.

2. Each specimen was radiographed. 
3. The length of the cobalt was estimated from the radiograph. Radiograph length was related to true length by calibration.

4. The weight of cobalt per specimen source strip was obtained by multiplying the weight of cobalt per unit length by the length of the cobalt. The weight of cobalt per unit length used for individual source strips was based on the samples from the following locations: first 3 strips from the front, front; next 4 strips, middle; last 3 strips, end.

\section{Calculated From Dimensions (CFD) Method:}

1 . The length of the cobalt was estimated from a radiograph of the specimen. Cobalt width and thickness were estimated by the difference between measured over-all width and thickness and cladding thickness. Cladding thickness for width was estimated from the radiograph; that for thickness from Magne-gage measurements.

2. The volume of cobalt was calculated. The weight of cobalt was calculated from the volume and the density of cobalt, reported in the literature as $8.85 \mathrm{~g} / \mathrm{cc}$ or $145.0 \mathrm{~g} / \mathrm{in}^{3}$.

\section{Solenoid Method:}

A destructive method of determining the weight of cobalt in each strip is the only method available at present. A nondestructive test obviously is desired.

\section{Method:}

Change of current in a solenoid with change in core dimensions. The flux in an ac electromagnet for a given impressed emf is approximately constant irrespective of the length of the air gap. Since the flux remains nearly constant, the variation in the current, $I$, is almost proportional to the length of air gap, $L_{a}$. If leakage and reluctance of the core are neglected, the current will be

$$
I=10^{7} E L_{a} / 2 f N A^{2},
$$

where

$E=$ effective value of impressed voltage, $V$,

$f=$ frequency of $V$, cycles/sec,

$\mathcal{N}=$ number of turns in the solenoid, and

$A=$ cross section area of the core, which in this application is the specimen.

By holding $E, L, f$, and $\mathcal{N}$ constant, the current is nearly proportional to $1 / A^{2}$. The weight of the cobalt is proportional to $1 / A^{2}$, assuming that the length of the cobalt is nearly constant and that the cladding is not magnetic. To express this concept quantitatively, let

$$
\begin{aligned}
W & =\text { weight of a strip of cobalt, } \\
L & =\text { length of the cobalt strip, } \\
v & =\text { volume, } \\
d & =\text { density of the cobalt, and } \\
k_{3}, k_{2}, k_{1}, k & =\text { constants. }
\end{aligned}
$$

Then,

$$
\begin{aligned}
I & =k_{3} / A^{2}, \\
W & =d v, \\
v & =A L, \\
W & =d A L=k_{2} A, \\
A & =k_{1} W, \\
I & =k_{3} /\left(k_{1} W\right)^{2}=k / W^{2}, \text { and } \\
\log I & =\log k-2 \log W .
\end{aligned}
$$

A schematic diagram of the method is shown in Figure B-9.

Apparatus:

Voltmeter: Hewlett-Packard, vacuum tube type, Model 410B.

Milliammeter: Weston, Model 904.

Power Source: Lambda Regulated Power Supply, with Variac ripple and noise, $5 \mathrm{mV}$ (rms) or less.

Solenoid: The solenoid was wound on a rectangular form made of phenolic plastic measuring $3 / 8 \times 1 \times 13$ in. with a center cavity $1 / 8 \times 3 / 4 \times 13$ in.
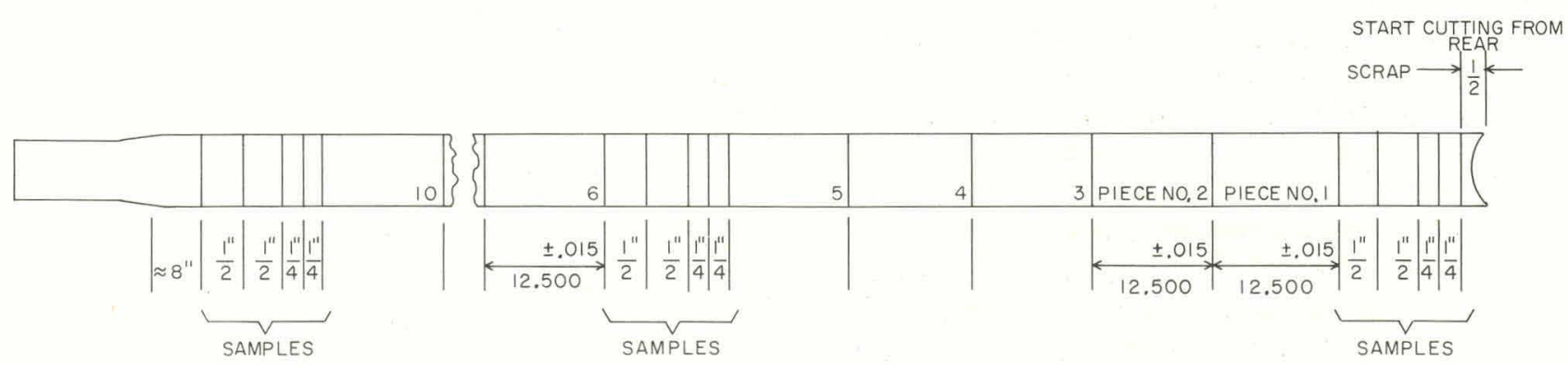

Figure B-8. Cutting diagram of drawn primary strips showing location of samples. 


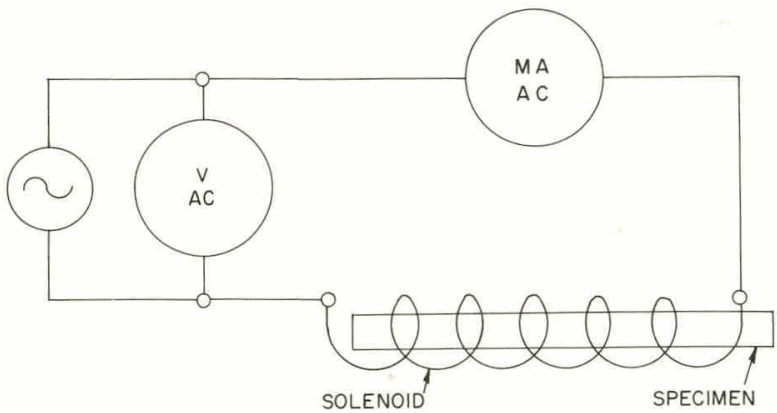

Figure B-9. Schematic of solenoid apparatus for determining weight of cobalt in bonded source.

A device for centering the specimen in the cavity was provided. The winding was about 5000 turns of 20-gauge copper wire insulated with Formex varnish.

Procedure:

1. After allowing time for instrument warm-up, a voltage was applied to the solenoid and the current reading was taken without the specimen. This is the reference current, $I_{0}$.

2. The specimen was inserted, centered, and the current, $I^{\prime}$, measured.

3 . The normalized specimen current, $I$, was calculated from the equation $I=234 I^{\prime} / I_{0}$. The coefficient 234 is an arbitrary standard reference current.

Calibration, Method A:

1. Strips of reactor-grade cobalt were machined to the nominal dimensions set by specification R155-W2, except that the thickness was varied so as to give a graded series of weighits.

2. After being weighed, the strips were placed in a stainless steel jacket and used as standards for calibration. The same jacket was used throughout to insure a constant effect from the stainless steel.

3. A plot of $\log I$ vs $\log W$ was made, with the data points enclosed by two lines of slope -2 (see Figure B-10).

Cialibration, Method B:

1. Production specimens were selected from regions of the primary strip adjacent to the samples for the NMI gravimetric determination of cobalt weight.

2. The weight of cobalt in these specimens was determined by the GR method.

3 . The specimen current was then measured in the solenoid apparatus.

4. A plot of $\log I$ vs $\log W$ was made as in Method $A$ (see Figure B-10).

\section{IXb. Cobalt Purity}

The certified analysis of the vendor was accepted.

\section{IXc. Cobalt Vacant Length on Ends}

The maximum distance from the end of the cobalt to the end of the strip was measured from the radiograph with the same procedures as in IIb.

\section{Xa. Outside Length}

The length was measured with a steel ruler to $1 / 32$ in. at the center. It was also measured by standing the specimen numbered end up and facing front on a surface plate with the right side of the specimen resting against a square. Two 0.250 in.-diam pins were placed between the bottom of the specimen and the surface plate. Measurement was made with a Federal Indicator reading to $\cap \cap n \cap 1$ in and a Cadillac gauge at i wo equispaced points.

\section{Xh Cutside Width}

The width was measured with a standard micrometer caliper to $0.0005 \mathrm{in}$. at cach end and centcr. It was also measured at intervals of $\approx 1 \mathrm{in}$. along the major axis, starting $\approx^{1 / 4} \mathrm{in}$. from the numbered end. Two 0.250 -in.-diam pins were used with a Pratt \& Whitney supermicrometer.

\section{Xc. Outside Thickness}

The thickness was measured with a standard micrometer caliper to $0.0001 \mathrm{in}$. at each end and center. It was also measured at intervals of $\approx 1 \mathrm{in}$. along the major axis, starting $\approx^{1 / 4} \mathrm{in}$. from the numhered end. A Pratt \& Whitney supermicromctcr was used.

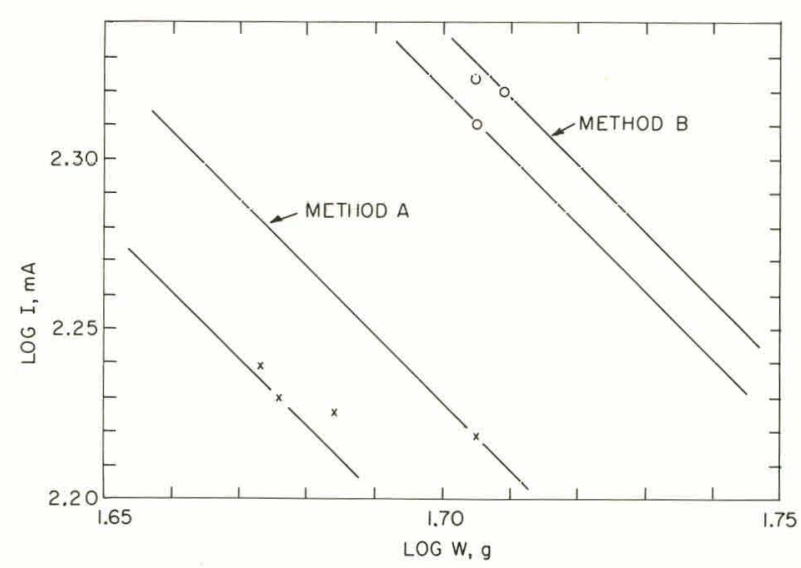

Figure B-10. Calibration curves for solenoid method. 


\section{Edge Form}

\section{A. Nondestructive Method:}

The specimens were inspected visually and by manual contact to determine whether the edges were broken.

\section{B. Destructive Method:}

The radius was measured on a photograph of a cross section taken perpendicular to the major axis. The geometric shape was also determined.

\section{Visual Examination}

Method:

Visual examination, aided by magnifying glass.
Apparatus:

Magnifying glass, $10 \times$.

Procedure:

Each specimen was examined for end weld continuity, bulging, burnished areas, striations, scratches, gouges, cracks, holes, soil (defined as any residue removable by rubbing with ashless analytical-grade filter paper), and stains (defined as any residue not so removable).

\section{APPENDIX C \\ RESULTS OF QUALITY CONTROL TESTS}

The following tabulation presents a summary of the results obtained. The lots are listed in chron-

Table C-1

III. Weld

\begin{tabular}{|c|c|c|c|c|c|c|c|c|}
\hline \multirow[b]{2}{*}{ Specification } & \multicolumn{2}{|c|}{ Lot 1} & \multicolumn{2}{|c|}{ Lot 2} & \multicolumn{2}{|c|}{ Lot 3} & \multicolumn{2}{|c|}{ Total } \\
\hline & $\mathrm{N}^{*}$ & $\% *$ & $\mathbf{N}$ & $\%$ & $\mathrm{~N}$ & $\%$ & $\mathrm{~N}$ & $\%$ \\
\hline \multicolumn{9}{|l|}{ I. Slab bow } \\
\hline A. Major axis, $<0.02 \mathrm{in.} / \mathrm{ft}$ & 48 & 100 & 55 & 100 & 65 & 100 & 168 & 100 \\
\hline B. Minor axis, $<0.0025$ in./in. & 48 & 100 & 55 & 100 & 65 & 100 & 168 & 100 \\
\hline \multicolumn{9}{|l|}{ II. Cladding thickness } \\
\hline A. Faces, 0.010 to $0.020 \mathrm{in}$. & 48 & 92 & 55 & 98 & 112 & 96 & 215 & 95 \\
\hline B. Edges, 0.010 to $0.020 \mathrm{in}$. & 10 & 80 & & & & & 10 & 80 \\
\hline C. Ends, no less than 0.015 in. & 60 & 93 & 59 & 88 & 143 & 92 & 262 & 92 \\
\hline D. Under holes, no less than $0.010 \mathrm{in.}$ & 47 & 89 & 55 & 87 & 69 & 91 & 171 & 89 \\
\hline \multicolumn{9}{|l|}{ III. Weld } \\
\hline A. Penetration and throat, no less than 0.015 in. & 60 & 93 & 59 & 88 & 143 & 92 & 262 & 92 \\
\hline B. Co concentration, no more than in cladding & 60 & 97 & 59 & 93 & & & 119 & 95 \\
\hline C. Overhang, no more than 0.005 in. & 60 & 81 & 55 & 71 & 94 & 66 & 207 & 72 \\
\hline \multicolumn{9}{|l|}{ IV. Nonbond of cobalt to cladding } \\
\hline A. Area, $<5 \%$ of bonded area & 50 & 100 & & & & & 50 & 100 \\
\hline B. Gap size, $<0.002$ in. & 50 & 100 & & & & & 50 & 100 \\
\hline V. Leak tightness, no leaks allowed & \multicolumn{8}{|c|}{ NOT TESTED } \\
\hline VI. Foreign material, none allowed & 50 & 98 & & & & & 50 & 98 \\
\hline VII. Ends, square within 0.015 in. & 48 & 96 & 55 & 100 & 67 & 97 & 165 & 98 \\
\hline VIII. Twist, $<5^{\circ} / \mathrm{ft}$ & 48 & 100 & 55 & 100 & 62 & 100 & 165 & 100 \\
\hline \multicolumn{9}{|l|}{ IX. Cobalt } \\
\hline A. Weight, 48 to $52 \mathrm{~g}$ & 52 & 100 & 59 & 100 & 63 & 100 & 174 & 100 \\
\hline B. Purity, reactor grade $99.5 \%$ & \multicolumn{8}{|c|}{ CERTIFIED ANALYSIS BY SUPPLIER } \\
\hline C. Vacant length on ends, no more than $1 / 8$ in. & 43 & 100 & 59 & 100 & 143 & 100 & 245 & 100 \\
\hline \multicolumn{9}{|l|}{$\mathrm{X}$. Outside dimensions } \\
\hline A. Length, $12^{15 / 32}$ to $12^{17 / 32}$ in. & 41 & 32 & & & 62 & 98 & 103 & 72 \\
\hline B. Width, 0.738 to 0.742 in. & 41 & 90 & & & 62 & 100 & 103 & 96 \\
\hline C. Thickness, 0.070 to $0.074 \mathrm{in}$. & 41 & 2 & & & 62 & 100 & 103 & 61 \\
\hline D. Thickness end to end, $<0.002$ in. & 40 & 100 & & & & & 40 & 100 \\
\hline \multicolumn{9}{|l|}{ XI. Edge form } \\
\hline $\begin{array}{l}\text { A. Rounded, } R=0.010 \text { to } 0.015 \text { in. } \\
\text { B. Chamfer, } 0.010 \text { in. min }\end{array}$ & 1 & 100 & & & & & 1 & 100 \\
\hline
\end{tabular}

${ }^{*} \mathrm{~N}=$ number inspected unless otherwise stated $\%=$ percentage passed. 
ological order of manufacture, lot 1 being the first.

\begin{tabular}{|c|c|c|}
\hline Lot No. & $\begin{array}{c}\text { Lot size (No. } \\
\text { of pieces examined) }\end{array}$ & $\begin{array}{l}\% \text { of lot meeting } \\
\text { all specifications }\end{array}$ \\
\hline 1 & 60 & 10 \\
\hline 2 & 59 & 12 \\
\hline 3 & 158 & 37 \\
\hline & 277 & 26 \\
\hline
\end{tabular}

A breakdown by specification and lot is given in Table G-1.

\section{Bow}

All the specimens in a sample of 168 were found to meet the specifications.

\section{Cladding Thickness}

\section{A. Faces:}

A sample of 215 specimens was tested by the Magne-gage method, and 95\% of the sample was found to meet the specification of 10 to 20 mils. This test measured an average cladding thickness on the two wide faces only, not on the two edges or the ends. Figure C-1 shows a calibration curve. Note that the curves obtained from standards made from specimens of two different lots differed by about $10 \%$.

Results of metallographic examination of two specimens are given in Table C-2. A comparison with results from the Magne-gage follows.

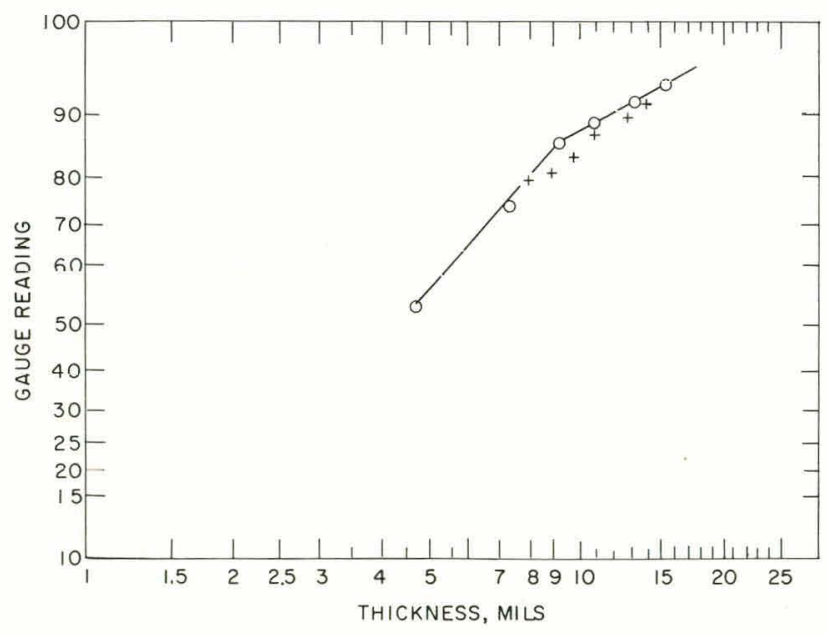

Figure C-1. Magne-gage calibration curve. The crosses show data obtained with a standard made from a prototype run specimen. For the data shown by the circles, the standard was made from a process qualifying run specimen.

Face cladding thickness, mils

\section{Specimen No. \\ $7-6-4$ \\ $7-6-5$}

\begin{tabular}{|c|c|}
\hline Magne-gage & Metallographic \\
\hline 14.7 to 15.7 & 15.0 to 17.9 \\
\hline $\begin{array}{l}\text { Met specification } \\
\text { (10 to } 20 \text { mils) }\end{array}$ & 15.6 to 18.7 \\
\hline
\end{tabular}

\section{B. Edges:}

Radiographic examination of a sample of 10 specimens showed the following results.

\begin{tabular}{|c|c|c|c|c|}
\hline \multirow[b]{2}{*}{ Specimen No. } & \multicolumn{4}{|c|}{$\begin{array}{l}\text { Edge cladding thickness, } \\
\pm 2 \text { mils }\end{array}$} \\
\hline & $1^{*}$ & $2^{*}$ & $3 * *$ & $4 * *$ \\
\hline $7-2-2$ & 19.3 & 19.5 & 15.8 & 16.1 \\
\hline-3 & 18.0 & 16.7 & 16.0 & 15.5 \\
\hline-4 & 16.2 & 19.0 & 15.7 & 15.7 \\
\hline-5 & 19.5 & 19.2 & 16.2 & 16.2 \\
\hline-6 & 17.5 & 17.5 & 19.0 & 15.5 \\
\hline-7 & 19.2 & 18.0 & 19.0 & 17.7 \\
\hline-8 & 16.5 & 16.7 & 17.5 & 18.7 \\
\hline-9 & 17.5 & 17.0 & 16.7 & 17.5 \\
\hline $7-6-4$ & 19.0 & 19.7 & 21.2 & 22.7 \\
\hline $7-6-5$ & 20.7 & 17.7 & 20.5 & 19.2 \\
\hline
\end{tabular}

*At corner of one edge.

**At corner of other edge.

Results of metallographic measurements made on a polished and etched cross section perpendicular to the major axis at the center of the edges were as follows.

\begin{tabular}{|c|c|c|}
\hline \multirow[b]{2}{*}{ Specimen No. } & \multicolumn{2}{|c|}{ Edge cladding thickness, mils } \\
\hline & Edge 1 & Edge 2 \\
\hline $7-6-4$ & 19.5 & 19.3 \\
\hline $7-6-5$ & 21.0 & 21.5 \\
\hline
\end{tabular}

These results compare with those obtained by the radiographic method. More work is required to improve the accuracy of the radiographic method.

\section{Ends:}

In a sample of 262 specimens examined by the radiographic method, $92 \%$ were found to meet specifications. Of those that did not, all were below the lower limit.

\section{Under Holes:}

From the first 60 pieces of the process qualifying run a sample of 48 was examined by the BNL dye penetrant method. One specimen was found to have a large cavity in a corner weld. Seven additional specimens were found to have one or more voids on their faces. These voids were not detected 
Table C-2

Thickness of Cladding on Stainless Steel Clad Cobalt Slab

(Measurements were made by metallographic examination of polished cross section at center of edges, at intervals of about 0.1 in. along faces.)

\begin{tabular}{ccc}
\hline & \multicolumn{2}{c}{ Thickness, mils } \\
\cline { 2 - 3 } Location on specimen & Specimen & Specimen \\
& $7-6-4$ & $7-6-5$ \\
\hline Face 1 & 17.9 & 18.7 \\
& 16.1 & 16.1 \\
& 15.3 & 16.0 \\
& 15.6 & 16.0 \\
& 15.3 & 16.0 \\
Arith. mean & 15.7 & 16.2 \\
Face 2 & 15.8 & 15.6 \\
& 17.5 & 16.1 \\
& 16.2 & 16.3 \\
& 17.1 & 17.1 \\
& 15.5 & 15.7 \\
& 16.3 & 16.7 \\
& 16.6 & 16.0 \\
Arith. mean & 16.3 & 17.0 \\
& 15.0 & 16.3 \\
& 15.2 & 16.6 \\
& 16.7 & 17.5 \\
& 16.1 & 16.6 \\
\hline
\end{tabular}

by radiography. The approximate depth ranged from 3 to 9 mils. Results given in Table C-3. Examination of 171 specimens showed that $89 \%$ met the specification.

\section{Weld}

\section{A. Penetration and Throat:}

A sample of 262 pieces was tested by the radiographic method. Of these, $92 \%$ met the specification.

\section{B. End Weld Contamination by Cobalt:}

Of a sample of 50 specimens tested by the BNL method, one specimen, 7-5-4, was found to have excessive cobalt in one weld. The same specimen was also reported by NMI to have excessive cobalt. In addition, NMI found excessive cobalt in another specimen which was not tested at BNL. Thus the number of defective specimens was 2 in 51 , or $3.9 \%$ of the sample.

Tables C- 4 to C-9 are results of the cobalt weld test made by the NMI method. The numbers rep-
Table C-3

Number and Size of Voids Found on Surface of Stainless Steel Clad Cobalt Slabs

(A sample of 48 slabs from the first 60 pieces of the process qualifying run by NMI was examined. Eight slabs were found with voids by dye penetrant method.)

\begin{tabular}{cccc}
\hline & & \multicolumn{2}{c}{ Approximate size of void } \\
\cline { 3 - 4 } Specimen No. & No. of voids & Diam, mils & Depth, mils \\
\hline $7-1-4$ & 1 & 3 & 3 \\
$7-1-8$ & 1 & 6 & 9 \\
$7-1-9$ & 3 & 3 & 3 \\
$7-4-2$ & 7 & 3 & 3 \\
$7-5-6$ & 2 & 4 & 6 \\
$7-5-9$ & 3 & 4.5 & 6 \\
$7-6-1$ & 1 & 3 & 3 \\
$7-6-8$ & 1 & 6 & 3 \\
& 3 & 3 & \multicolumn{2}{c}{ of weld } \\
\hline
\end{tabular}

resent the time, in seconds, required for a given count to be reached. Of a sample of 60 specimens examined, 2 specimens, or $3 \%$ of the sample, were found to be defective.

\section{Overhang:}

Seventy-two percent of 207 pieces met the specification. Those not meeting the specification were 6 to 10 mils oversize.

\section{Bond Integrity, Over-All Continuity}

\section{A. Nonbond of Cobalt to Cladding:}

The ultrasonic test was arranged to reveal discontinuities within the first 20 mils of metal from the surface examined. Of 48 specimens examined, 44 were free of discontinuities. The 4 specimens showing a discontinuity had a discontinuous area of $<1 \%$ of the total area of one side. All four specimens showed discontinuities on one side only. The reflection given by 7-5-1 was faint. This specimen was rerun twice and the reflection did not show. Figure C-2 shows the discontinuity revealed by ultrasonic test of specimen 7-6-5. Metallographic examination of this discontinuity showed that it was neither a nonbond nor a void (see section VI, Foreign Materials). 
Table C-4

X-Ray Fluorescent Test for Cobalt in End Welds, Source Strip 7-1

\begin{tabular}{crr}
\hline Sample No. & \multicolumn{2}{c}{ Time, sec } \\
\hline $7-1-1$ & 10.9 & 10.8 \\
$7-1-2$ & 11.7 & 12.2 \\
& 12.0 & 12.0 \\
$7-1-3$ & 12.5 & 11.2 \\
& 12.2 & 11.7 \\
$7-1-4$ & 12.2 & 13.0 \\
& 13.8 & 13.2 \\
$7-1-5$ & 12.3 & 12.8 \\
$7-1-6$ & 10.9 & 12.4 \\
& 12.6 & 12.0 \\
$7-1-7$ & 12.1 & 11.5 \\
& 12.4 & 10.8 \\
$7-1-8$ & 12.2 & 11.5 \\
& 11.4 & 11.8 \\
$7-1-9$ & 11.5 & 9.7 \\
& 10.3 & 10.4 \\
$7-1-10$ & 10.5 & 11.4 \\
& 10.7 & 11.7 \\
& 12.7 & 10.4 \\
& 13.2 & 11.0 \\
\hline
\end{tabular}

Table C-6

X-Ray Fluorescent Test for Cobalt in End Welds, Source Strip 7-3

\begin{tabular}{ccc}
\hline Sample Nn & \multicolumn{2}{c}{ Time. sec } \\
\hline $7-3-1$ & 11.4 & 12.3 \\
& 11.6 & 12.6 \\
$7-3-2$ & 11.5 & 11.0 \\
& 12.5 & 12.4 \\
$7-3-3$ & 10.5 & 12.2 \\
& 11.8 & 11.4 \\
$7-3-4$ & 11.6 & 12.7 \\
& 11.6 & 11.0 \\
$7-3-5$ & 11.2 & 12.7 \\
& 12.2 & 11.5 \\
$7-3-7$ & 10.4 & 11.1 \\
& 12.3 & 11.1 \\
$7-3-8$ & 11.6 & 12.0 \\
& 11.9 & 12.7 \\
$7-3-9$ & 10.7 & 11.1 \\
& 12.6 & 13.4 \\
$7-3-10$ & 11.7 & 13.3 \\
& 11.9 & 12.0 \\
& 11.4 & 13.0 \\
& 12.0 & 12.3 \\
\hline
\end{tabular}

Table C-5

X-Ray Fluorescent Test for Cobalt in End Welds, Source Strip 7-2

\begin{tabular}{crr}
\hline Sample No. & \multicolumn{2}{c}{ Time, sec } \\
\hline $7-2-1$ & 10.4 & 11.7 \\
$7-2-2$ & 11.4 & 10.4 \\
& 11.2 & 10.3 \\
$7-2-3$ & 9.6 & 10.5 \\
$7-2-4$ & 10.3 & 13.3 \\
& 13.0 & 10.0 \\
$7-2-5$ & 10.4 & 13.4 \\
& 10.5 & 13.3 \\
$7-2-6$ & 13.8 & 11.3 \\
$7-2-7$ & 11.0 & 11.6 \\
& 11.6 & 10.5 \\
$7-2-8$ & 11.1 & 11.3 \\
& 11.6 & 13.4 \\
$7-2-9$ & 11.1 & 12.5 \\
$7-2-10$ & 13.0 & 10.7 \\
& 11.8 & 13.7 \\
& 11.2 & 12.4 \\
& 13.9 & 10.0 \\
\hline \hline
\end{tabular}

Table C-7

X-Ray Fluorescent Test for Cobalt in End Welds, Source Strip 7-4

\begin{tabular}{|c|c|c|}
\hline Sample No. & \multicolumn{2}{|c|}{ Time, sec } \\
\hline $7-4-6$ & $\begin{array}{l}12.60 \\
12.30\end{array}$ & $\begin{array}{l}10.25 \\
12.30\end{array}$ \\
\hline $7-4-9$ & $\begin{array}{l}11.80 \\
12.10\end{array}$ & $\begin{array}{l}11.45 \\
11.50\end{array}$ \\
\hline $7-4-7$ & $\begin{array}{l}12.5 .5 \\
12.30\end{array}$ & $\begin{array}{l}11.80 \\
11.70\end{array}$ \\
\hline $7-4-10$ & $\begin{array}{l}11.75 \\
11.50\end{array}$ & $\begin{array}{l}11.20 \\
11.20\end{array}$ \\
\hline $7-4-5$ & $\begin{array}{l}11.55 \\
11.35\end{array}$ & $\begin{array}{l}11.20 \\
11.70\end{array}$ \\
\hline $7-4-2$ & $\begin{array}{l}11.65 \\
12.10\end{array}$ & $\begin{array}{r}9.80 \\
12.20\end{array}$ \\
\hline $7-4-4$ & $\begin{array}{l}11.55 \\
11.80\end{array}$ & $\begin{array}{l}11.90 \\
11.70\end{array}$ \\
\hline $7-4-3$ & $\begin{array}{l}11.70 \\
11.65\end{array}$ & $\begin{array}{l}12.00 \\
11.75\end{array}$ \\
\hline $7-4-1$ & $\begin{array}{l}11.40 \\
11.25\end{array}$ & $\begin{array}{l}11.70 \\
12.50\end{array}$ \\
\hline $7-4-8$ & $\begin{array}{l}11.50 \\
11.15\end{array}$ & $\begin{array}{l}10.25 \\
10.50\end{array}$ \\
\hline
\end{tabular}


Table C-8

X-Ray Fluorescent Test for Cobalt in End Welds, Source Strip 7-5

\begin{tabular}{ccc}
\hline Sample No. & \multicolumn{2}{c}{ Time, sec } \\
\hline $7-5-3$ & 12.70 & 13.00 \\
$7-5-7$ & 12.60 & 12.45 \\
& 12.65 & 12.65 \\
$7-5-6$ & 12.20 & 12.95 \\
& 12.60 & 12.35 \\
$7-5-5$ & 12.65 & 13.00 \\
& 12.10 & 12.30 \\
$7-5-2$ & 12.05 & 11.90 \\
$7-5-8$ & 12.35 & 12.05 \\
& 12.20 & 12.25 \\
$7-5-9$ & 11.70 & 12.85 \\
& 11.95 & 12.90 \\
$7-5-10$ & 12.60 & 12.40 \\
& 12.80 & 12.35 \\
$7-5-4$ & 11.70 & 11.55 \\
& 12.20 & 12.05 \\
$7-5-1$ & 12.60 & 11.40 \\
& 12.40 & 11.80 \\
& 12.40 & 11.95 \\
& 12.85 & 12.20 \\
\hline & & \\
\hline
\end{tabular}

X-Ray Fluorescent Test for Cobalt in End Welds, Source Strip 7-6

\begin{tabular}{|c|c|c|}
\hline Sample No. & \multicolumn{2}{|c|}{ Time, sec } \\
\hline $7-6-2$ & $\begin{array}{r}10.00 \\
9.60\end{array}$ & $\begin{array}{l}10.60 \\
10.65\end{array}$ \\
\hline $7-6-4$ & $\begin{array}{l}10.25 \\
10.20\end{array}$ & $\begin{array}{l}10.80 \\
10.00\end{array}$ \\
\hline $7-6-3$ & $\begin{array}{l}11.40 \\
11.15\end{array}$ & $\begin{array}{r}10.10 \\
9.85\end{array}$ \\
\hline $7-6-1$ & $\begin{array}{l}10.05 \\
10.00\end{array}$ & $\begin{array}{l}9.75 \\
9.95\end{array}$ \\
\hline $7-6-10$ & $\begin{array}{l}10.30 \\
10.15\end{array}$ & $\begin{array}{r}10.10 \\
6.80\end{array}$ \\
\hline $7-6-9$ & $\begin{array}{l}10.85 \\
10.70\end{array}$ & $\begin{array}{l}11.05 \\
10.60\end{array}$ \\
\hline $7-6-8$ & $\begin{array}{l}11.00 \\
10.75\end{array}$ & $\begin{array}{l}10.65 \\
10.60\end{array}$ \\
\hline $7-6-7$ & $\begin{array}{l}11.00 \\
10.80\end{array}$ & $\begin{array}{l}10.15 \\
10.70\end{array}$ \\
\hline $7-6-6$ & $\begin{array}{l}11.40 \\
11.70\end{array}$ & $\begin{array}{l}11.50 \\
11.80\end{array}$ \\
\hline $7-6-5$ & $\begin{array}{l}11.20 \\
11.10\end{array}$ & $\begin{array}{l}11.05 \\
11.20\end{array}$ \\
\hline Blank & $\begin{array}{r}9.80 \\
10.50\end{array}$ & $\begin{array}{l}10.20 \\
10.50\end{array}$ \\
\hline
\end{tabular}

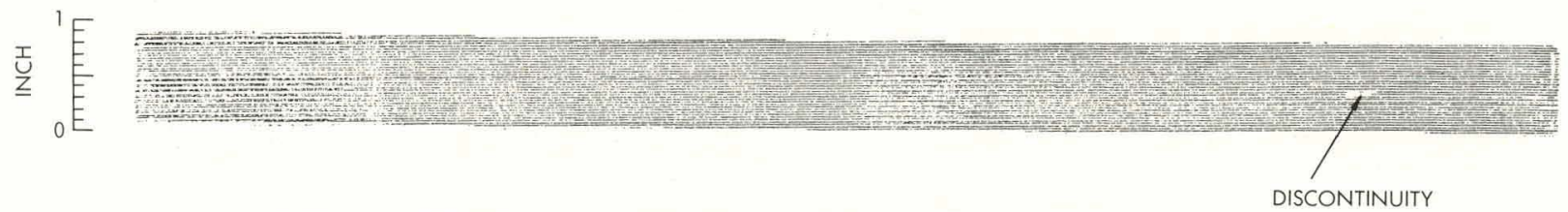

Figure G-2. Ultrasonic test of specimen 7-6-5 showing discontinuity in stainless steel bonded cobalt source.

\section{B. Gaps and Voids:}

Figures C-3 to G-13 show results obtained on some of the specimens. These results illustrate the range in surface temperature differences. The single peak located about 4 to $5 \mathrm{in}$. from the left end of the upper scan and the two peaks located about 2 to 3 and 6 to $7 \mathrm{in}$., respectively, from the left of the lower scan are due to the specimen holder knobs that held the specimen at these points on the edges.

Figures C-4, C-7, C, 10, and C-11 show possible discontinuity of low thermal conductivity. These areas show a correlation with areas of low density on the radiographs.

\section{Leak Tightness}

No tests were made for the reason given in the description of the method, Appendix B, section V.

\section{Foreign Materials}

The discontinuity revealed by ultrasonic test of specimen 7-6-5 was found by metallographic examination to be a high concentration of foreign inclusions in the stainless steel cladding. A low concentration of these inclusions or "dirt" is often found in austenitic stainless steels. Usually the inclusions are uniformly distributed. 


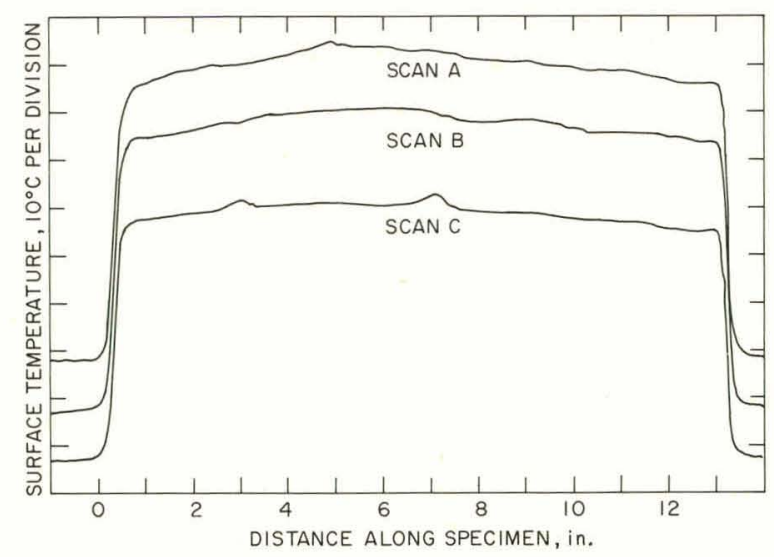

Figure C-3. Thermal test of specimen 7-3-5.

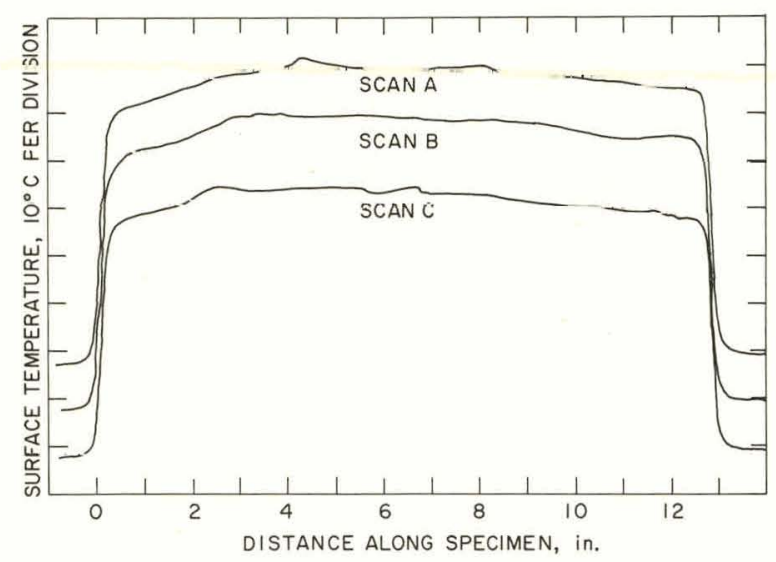

Figure C-5. Thicimal test of opecimen $7-4-10$

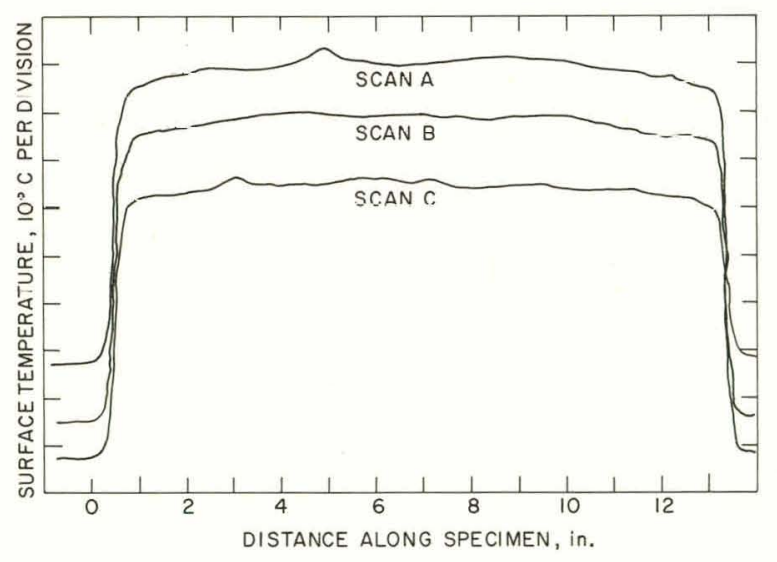

Figure C-7. Thermal test of specimen 7-5-1.

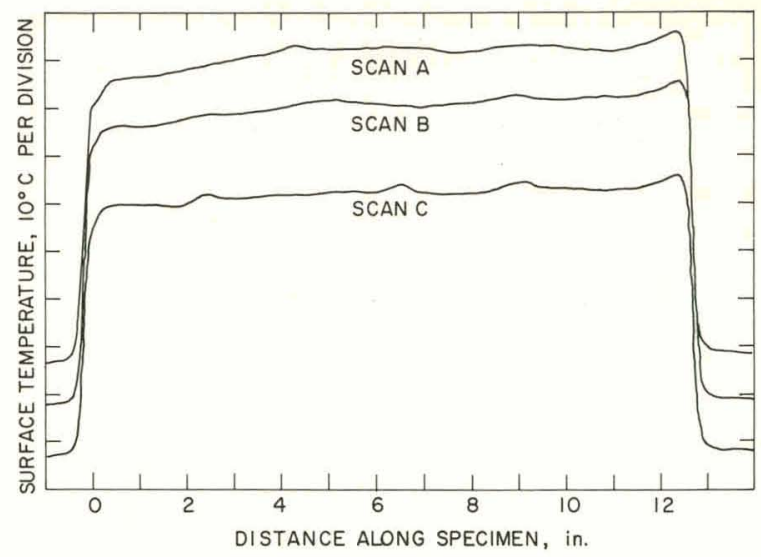

Figure C-4. Thermal test of specimen of 7-3-8.

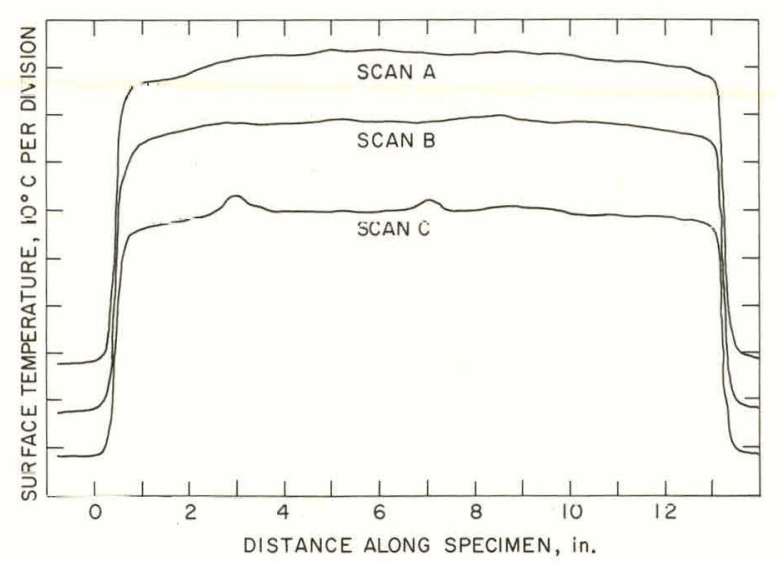

Figure G-6. Thermal test of specimen 7-4-10 (second side).

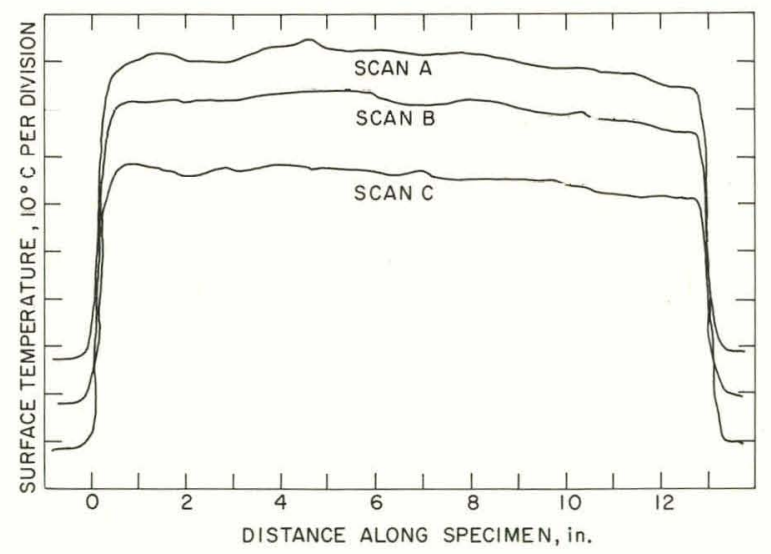

Figure C-8. Thermal test of specimen 7-5-3. 


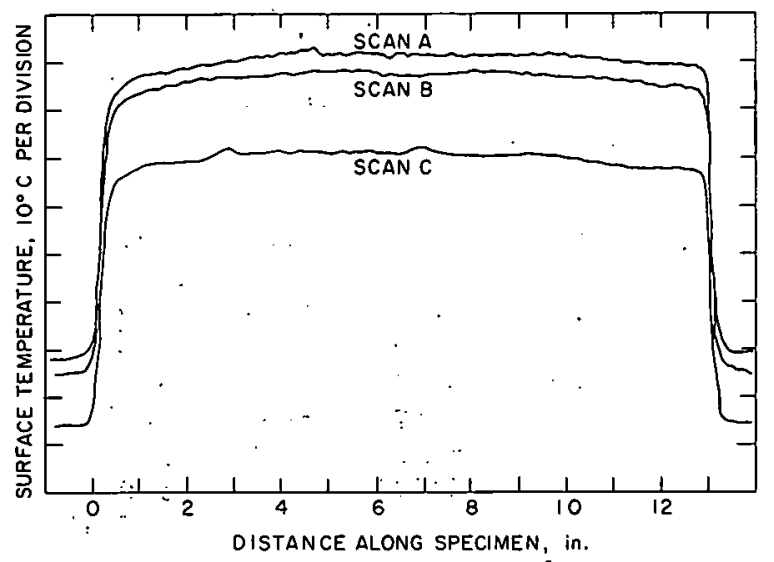

Figure C-9. Thermal test of specimen 7-5-3 (second side).

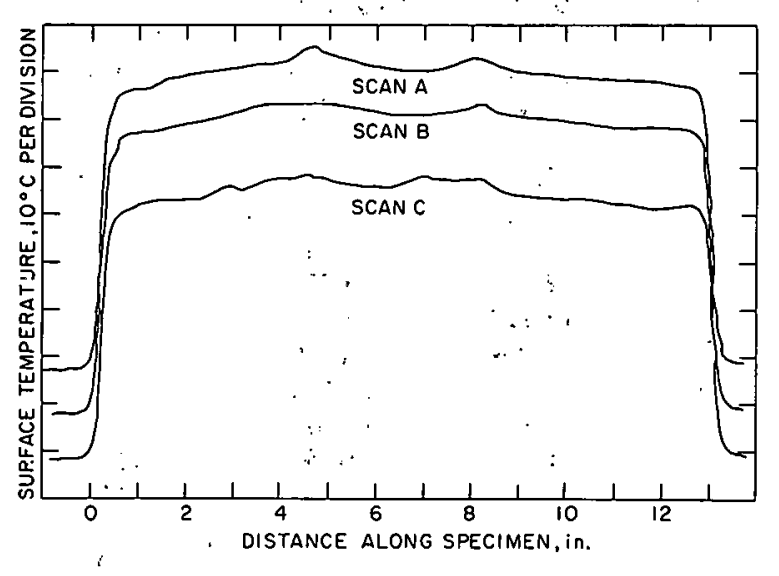

Figure C-11. Thermal test of specimen 7-6-4.

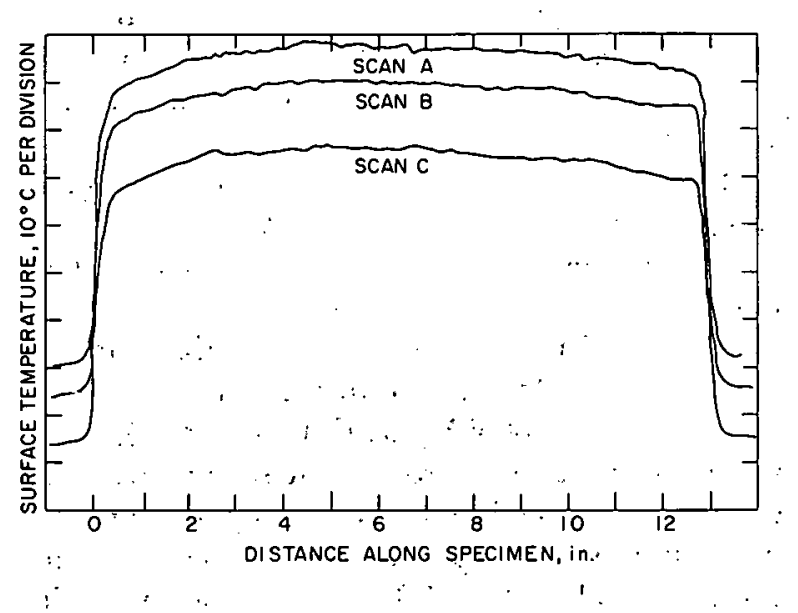

Figure C-13. Thermal test of specimen 7-6-7.

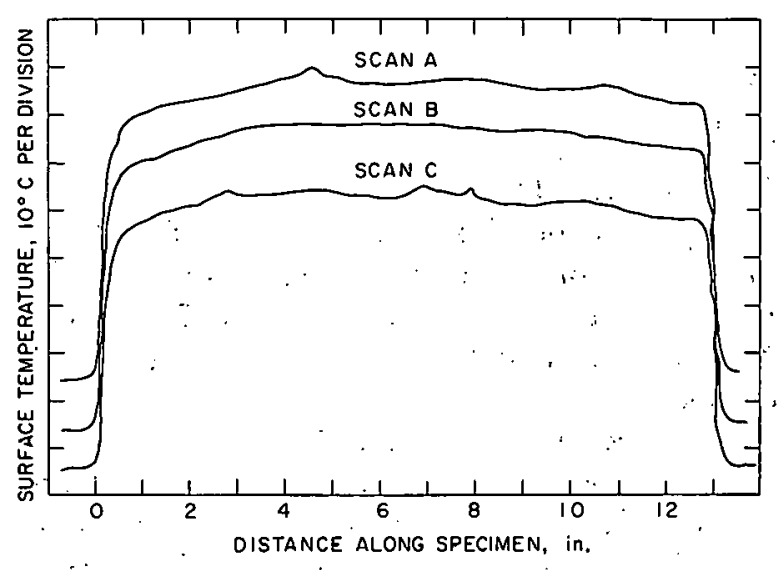

Figure C-10. Thermal test of spécimen 7-6-1.

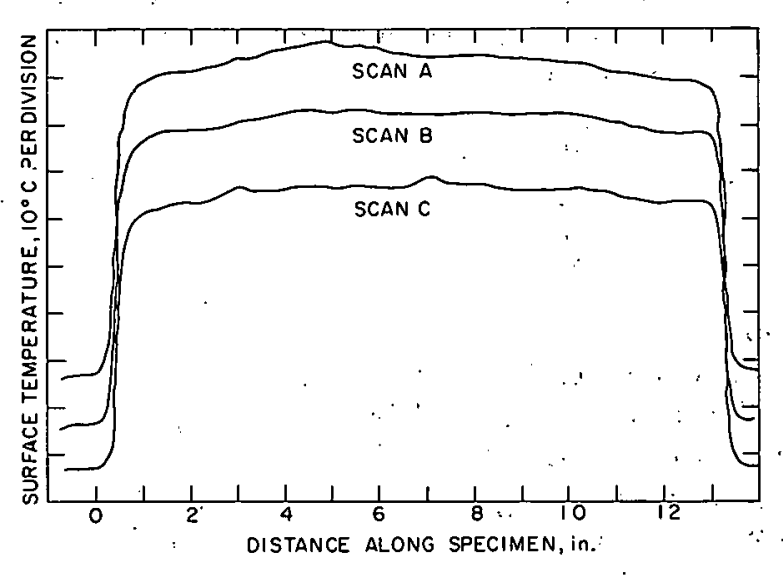

Figure C-12. Thermal test of specimen 7-6-5. 


\section{Squareness of Ends}

Of a sample of 165 specimens, $98 \%$ were found to meet specifications. The remaining specimens were 2 to 4 mils oversize.

\section{Twist}

All the specimens in a sample of 165 were found to meet specifications.

\section{Cobalt}

\section{A. Weight:}

Gravimetric Method:

Results reported by $\mathrm{P}$. Lowenstein of $\mathrm{NMI}$ are given in Table C-10. The weight of cobalt in 6 primary source strips ranged from 50.7 to $51.6 \mathrm{~g}$. Note that the weight is based on an average length of cobalt.

\section{Gravimetric-Radiograph (GR) Method:}

Samples were taken from primary strips 7-2 to 7-6. Results for 17 specimens are given in Table C.-11. Note that 8 slabs, all from one primary strip (7-2), ranged in weight from 50.9 to $51.2 \mathrm{~g}$. The weights of the remaining source strips ranged from 51.0 to $51.6 \mathrm{~g}$.

Calculated From Dimensions (CFD) Method:

The results of measurements on one specimen are given below.

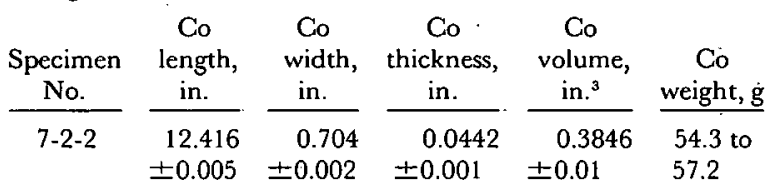

Snt.finoIn Mrthon:

The result of the first try using rcactor-gradc cobalt is given in Figure C-14, which is a plot of the logarithm of the solenoid current $(I)$ in milliamperes vs the logarithm of the weight of cobalt $(W)$ in grams. Each point in Figure C-14, curves (1) and (2), is the arithmetic mean of two and three runs, respectively. The range of all replicate runs was within the circle data point symbol. Applied voltage was $8 \mathrm{~V}$ ac.

Figure C-14, curve (2), is the result of the first try using calibration method $A$ and specimens machined from Sherrit Gordon cobalt in the asreceived condition. The weights ranged from 47 to $52 \mathrm{~g}$. It can be seen that the relation is linear, in agreement with theory. Some individual data points deviate widely. Curve (1) in Figure C-14 is a similar plot from a lot of Kulite-Tungsten cobalt that had been annealed by the manufacturer after
Table C-10

Weight of 12.425-in.-Long Cobalt Slab, g

\begin{tabular}{ccccc}
\hline Strip No. & End & Middle & Front & $\begin{array}{c}\text { Range, } \\
\text { smallest to } \\
\text { largest }\end{array}$ \\
\hline $7-1$ & 51.516 & 51.305 & 51.578 & 51.3 to 51.6 \\
$7-2$ & 51.245 & 51.190 & 50.852 & 50.9 to 51.2 \\
$7-3$ & 51.470 & 51.397 & 51.443 & 51.4 to 51.5 \\
$7-4$ & 51.166 & 50.971 & 51.398 & 51.0 to 51.4 \\
$7-5$ & 50.774 & 51.461 & 50.701 & 50.7 to 51.5 \\
$7-6$ & 51.244 & 50.977 & 51.195 & 51.0 to 51.2 \\
All & - & - & - & 50.7 to 51.6 \\
\hline \hline
\end{tabular}

\begin{tabular}{cccc}
\hline \multicolumn{4}{c}{ Table C-11 } \\
\hline $\begin{array}{c}\text { Eprininin } \\
\text { No. }\end{array}$ & $\begin{array}{c}\text { Length } \\
\text { uf Cu, it. } \\
\pm 0.005 \text { in. }\end{array}$ & $\begin{array}{c}\text { Weight of } \\
\text { Cu per unili } \\
\text { length, g/in. }\end{array}$ & $\begin{array}{c}\text { Weight of Cio } \\
\text { per slab, g }\end{array}$ \\
\hline $7-2-2$ & 12.417 & 4.1243 & 51.21 \\
-3 & 12.418 & 4.1243 & 51.22 \\
-4 & 12.429 & 4.1199 & 51.20 \\
-5 & 12.430 & 4.1199 & 51.21 \\
-6 & 12.424 & 4.1199 & 51.18 \\
-7 & 12.416 & 4.1199 & 51.15 \\
-8 & 12.436 & 4.0927 & 50.89 \\
--9 & 12.440 & 4.0927 & 50.91 \\
$7-3-5$ & 12.394 & 4.1366 & 51.27 \\
$-3-8$ & 12.404 & 4.1430 & 51.36 \\
$-4-10$ & 12.303 & 4.1367 & 51.89 \\
$-5-1$ & 12.402 & 4.0864 & 50.68 \\
$-5-3$ & 12.412 & 4.0864 & 50.72 \\
$-5-10$ & 12.412 & 4.0806 & 50.65 \\
$-6-1$ & 12.379 & 4.1243 & 51.05 \\
$-6-4$ & 12.380 & 4.1028 & 51.79 \\
$-6-7$ & 12.378 & 4.1028 & 51.78 \\
\hline & & & \\
\hline
\end{tabular}

being formed (probably by rolling) into strips. The weights ranged from 23 to $28.5 \mathrm{~g}$. The relation is again linear, individual deviation is smaller than in calibration method $B$, but the slope is markedly different from theory. The change in slope suggests that each lot of cobalt will have to be ralibrated until the cause of the deviation from theory is found.

Figure C-15 is a comparison of calibrations by both methods. It is apparent that calibration by method $A$, a replot of Figure C-14, curve (2), is not valid for the actual production specimens. The most likely reason for the discrepancy is differences in the magnetic properties of the cobalt and the stainless steel due to different processing conditions. Calibration method $B$ was selected for the 


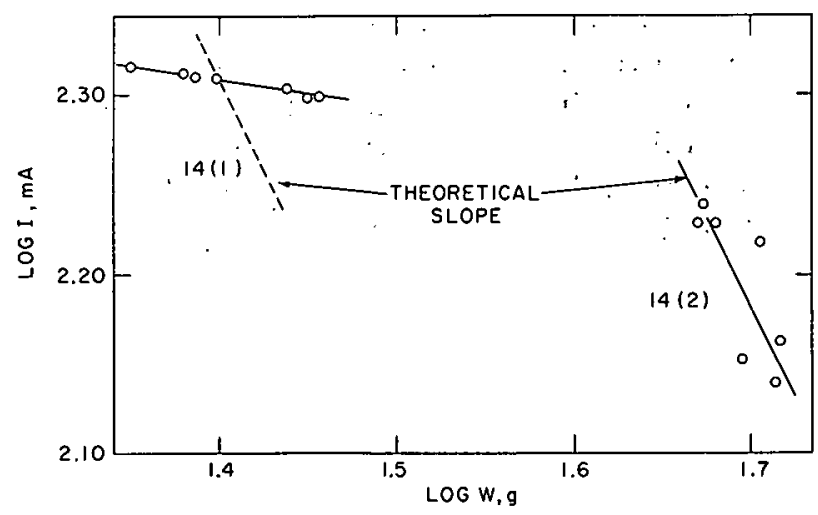

Figure C-14. Preliminary calibration for solenoid method.

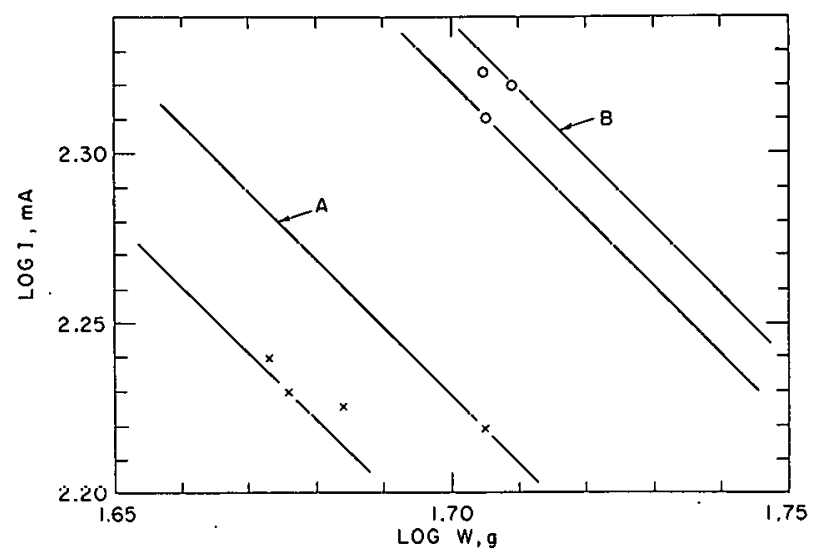

Figure C-15. Calibration curves for solenoid method.

production specimens. For this calibration, at a cobalt weight of $50 \mathrm{~g}$, the uncertainty is about $\pm 0.5 \mathrm{~g}$. More work will be needed to reduce this uncertainty and to make the method independent of processing conditions.

Results of solenoid measurements with calibration method $R$ on a sample of 51 specimens showed that the cobalt weight for all specimens ranged somewhere between 49.9 and $51.7 \mathrm{~g}$, within the range set by the specifications ( 48 to $52 \mathrm{~g}$ ).

A comparison of the results by the various methods is given in Table C.12. The result with the CFD method was 8 to $14 \%$ higher than that from the other methods. This is probably due to the relatively large errors in the measurements of the dimensions, to the assumption of a slah of true rectangular cross section, and to the assumption that density was theoretical. Microscopic examination shows some voids in the cobalt; thus the true density was less than the theoretical density.
Table C-12

Weight of Cobalt in Stainless Steel Clad Cobalt Slabs

(Results of various methods are compared. Specification allows a weight range of 48 to $52 \mathrm{~g}$.)

\begin{tabular}{lrr}
\hline \multicolumn{1}{c}{ Method } & $\begin{array}{c}\text { Sample } \\
\text { size }\end{array}$ & $\begin{array}{l}\text { Range in } \\
\text { weight of } \\
\text { cobalt, } g\end{array}$ \\
\hline Gravimetric (NMI) & 18 & 50.7 to 51.6 \\
Gravimetric-radiograph (GR) & 17 & 50.9 to 51.6 \\
Calculated from dimensions (CFD) & 1 & 54.3 to 57.2 \\
Solenoid & 51 & 49.9 to 51.7 \\
\hline
\end{tabular}

\section{B. Purity:}

The analysis of the cobalt was certified by the supplier, the Kulite-Tungsten Co. No further analyses were done. The Savannah River Plant has recently set specifications for reactor-grade cobalt. These will be included in future specifications for the bonded source.

\section{Xa. Outside Length}

Of 103 specimens measured with a steel ruler, $72 \%$ were found to meet specifications. Those remaining were all $1 / 32$ in. oversize.

\section{Xb. Outside Width}

Of a sample of 103 specimens measured with a standard micrometer caliper, $96 \%$ were found to meet specifications. Those remaining were 0.4 to 1 mil oversize.

\section{Xc. Outside Thickness}

In a sample of 103 specimens similarly measured, $61 \%$ were found to meet specifications. Those remaining were $1 \mathrm{mil}$ nversize.

\section{Xd. Outside Thickness End to End}

Of a sample of 40 specimens, $100 \%$ were found to meet the specifications.

\section{Xe. Outside Dimension Variability}

To get an idea of the amount of variability within a single specimen, measurements of outside length, width, and thickness were made on specimen 7-6-10 by using the alternative method described in Appendix B, section X. Results are given below. 
No. of

Measure- measurement, in. ments

Length

Width

Thickness

12

\begin{tabular}{|c|c|c|c|}
\hline Min & Max & $\begin{array}{l}\text { Arith. } \\
\text { mean }\end{array}$ & $\begin{array}{l}\text { Standard } \\
\text { deviation }\end{array}$ \\
\hline 12.7731 & 12.7836 & 12.7784 & 0.0074 \\
\hline 0.7418 & 0.7424 & 0.7420 & 0.00024 \\
\hline 0.0738 & 0.0740 & 0.0739 & 0.00008 \\
\hline
\end{tabular}

\section{Edge Form}

One specimen was examined by the destructive method. It met the specification.

\section{Visual Examination}

Visual examination was not systematically done on all specimens. Striations were observed on several specimens. They were located near the center of and parallel to the long axis of the wide faces. Some were several inches long. These probably are a result of the extrusion process. 